\title{
An Intensive Pedestrian Archaeological Survey of a 117-acre Park in Kendall County, Texas
}

Cynthia Moore Munoz

Center for Archeological Research, University of Texas at San Antonio

Follow this and additional works at: https://scholarworks.sfasu.edu/ita

Part of the American Material Culture Commons, Archaeological Anthropology Commons, Environmental Studies Commons, Other American Studies Commons, Other Arts and Humanities Commons, Other History of Art, Architecture, and Archaeology Commons, and the United States History Commons

Tell us how this article helped you.

This Article is brought to you for free and open access by the Center for Regional Heritage Research at SFA ScholarWorks. It has been accepted for inclusion in Index of Texas Archaeology: Open Access Gray Literature from the Lone Star State by an authorized editor of SFA ScholarWorks. For more information, please contact cdsscholarworks@sfasu.edu. 


\section{An Intensive Pedestrian Archaeological Survey of a 117-acre Park in Kendall County, Texas}

\section{Creative Commons License}

\section{(c) (1) \&}

This work is licensed under a Creative Commons Attribution-NonCommercial 4.0 International License 


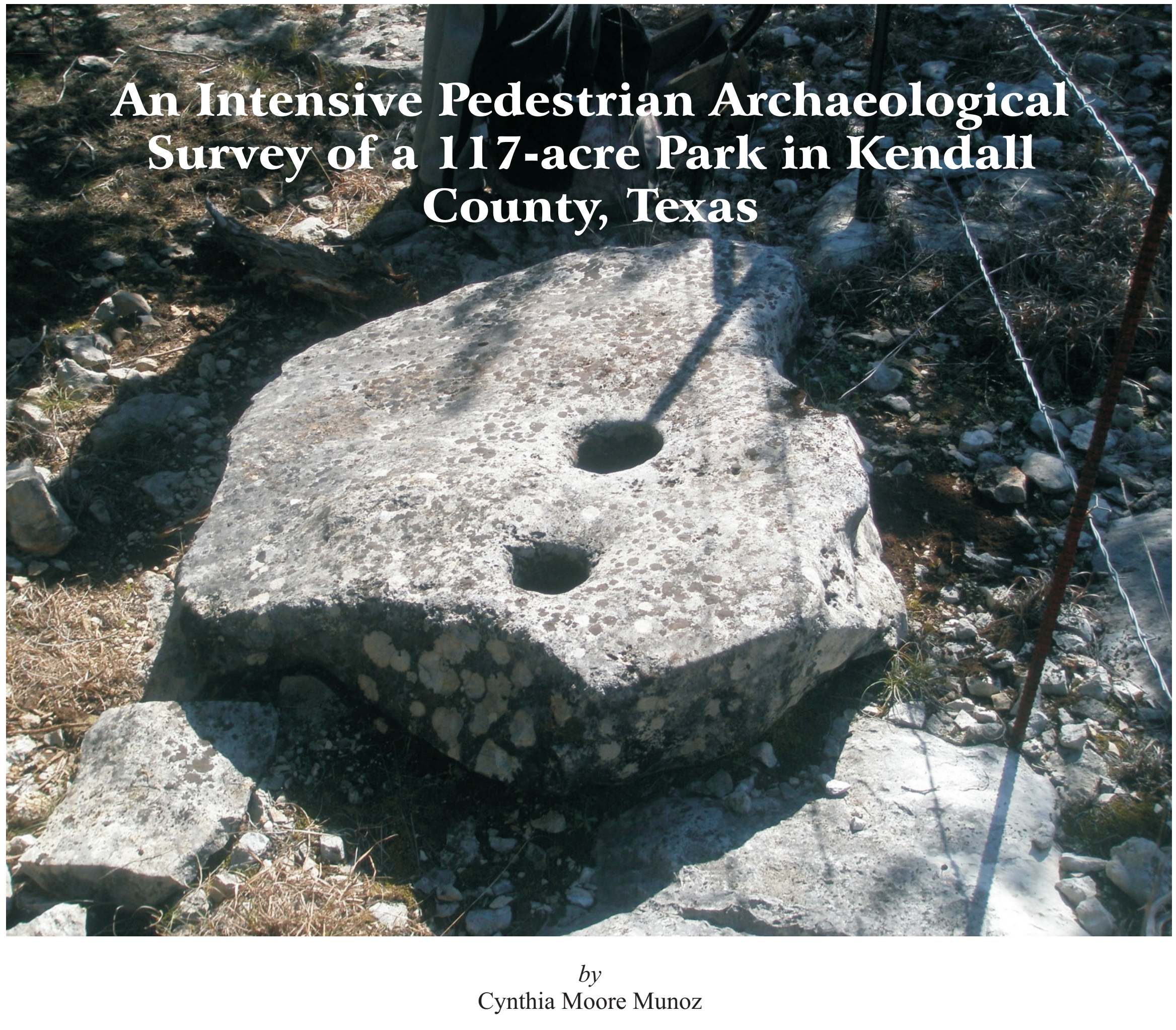

Texas Antiquities Permit No. 5540

Prepared for:

The Commissioner's Court of Kendall County 201 East San Antonio Street, Suite 101 Boerne, Texas 78006

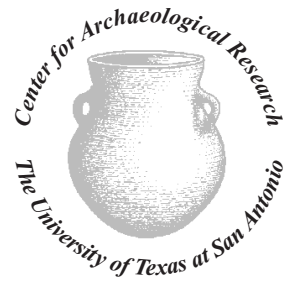

(C)2010

\section{Prepared by:}

Center for Archaeological Research The University of Texas at San Antonio Archaeological Report, No. 411 


\title{
An Intensive Pedestrian Archaeological Survey of a 11 7-acre Park in Kendall County, Texas
}

\author{
by \\ Cynthia Moore Munoz
}

Texas Antiquities Committee Permit No. 5540

Principal Investigator

Raymond P. Mauldin

Prepared for:

The Commissioner's Court of Kendall County 201 East San Antonio Street, Suite 101 Boerne, Texas 78006

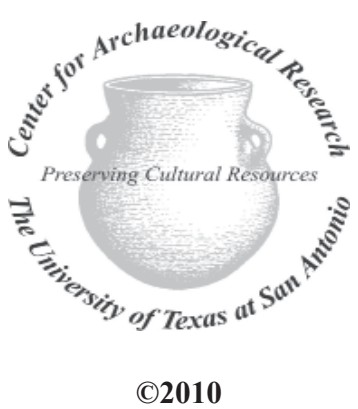

Prepared by:

Center for Archaeological Research The University of Texas at San Antonio Archaeological Report No. 411 



\begin{abstract}
:
During February 2010, The Center for Archaeological Research (CAR) of The University of Texas at San Antonio (UTSA) conducted an intensive pedestrian archaeological survey of the Kendall County Park project located near Boerne, Texas to fulfill contract requirements with the Commissioner's Court of Kendall County. The survey was conducted under the requirements of Section 106 of the National Historic Preservation Act (NHPA) of 1966 and the Texas Antiquities Code. The survey was performed under Texas Antiquities Permit No. 5540, with Dr. Raymond Mauldin, CAR Assistant Director, serving as Principal Investigator and Cynthia Moore Munoz serving as the Project Archaeologist. The work was conducted in advance of proposed improvements to the property.
\end{abstract}

The park will consist of picnic areas, trails, a park road, and a two parking areas. Road improvements, parking, and trails will be designed to minimize soil disturbance and erosion. No excavation is anticipated during construction. The principal goal of the pedestrian survey was to identify and document all prehistoric and/or historic archaeological sites that may be impacted by the proposed improvements within the park. This report summarizes the results of the fieldwork and provides recommendations regarding the management of cultural resources located on the project area.

Pedestrian reconnaissance, 64 shovel tests, and 2 backhoe trenches were used to search for cultural resources along the existing park road and on the 117-acre project area. Eighteen isolated surface finds, including debitage, tools, one core, and burned rock, in addition to an isolated find consisting of two mortar holes in a large boulder, were documented. The mortar holes are located in an area of exposed bedrock. No surface artifacts were noted within a 30 meter radius of the mortar holes.

One new site, 41KE214, was documented within the project area. The site, consisting of a low density surface scatter of lithic debitage, tools, and burned rock without associated staining or charcoal, is located directly on the park road. Shovel tests excavated to delineate the site were all negative. No diagnostic artifacts were noted. The lack of material depth, features, and diagnostics, suggests that 41KE214 possesses a low potential for future research value and, therefore, the CAR recommends that the site be considered ineligible for listing on the National Register of Historic Places. Two sinkholes and one cave were documented during the pedestrian reconnaissance. The openings of all three are large and the depth of each is substantial making them potential locations of prehistoric human interments. Because safety concerns prohibited subsurface investigation of the cave and sinkholes, it is not known if the geological features contain interments or other cultural materials. However, due to the preponderance of cave and sinkhole burials on the Edwards Plateau, there is some likelihood for prehistoric human use. The CAR recommends that the cave and sinkhole openings be protected to prevent exploration and looting of potential cultural material until these locations are assessed for significance.

Upon completion of the CAR's shovel testing of site 41KE214, the Texas Historic Commission requested the excavation of additional shovel tests to confirm the extent of the site and the lack of deep deposits. The CAR excavated 22 additional shovel tests on and around 41KE214 to supplement the ones excavated previously resulting in 34 shovel tests associated with the site; 10 in the boundaries and 24 in the immediate area. Of the 34 shovel tests, 1 was positive. This test, which terminated upon the exposure of bedrock at $4 \mathrm{cmbs}$, produced two pieces of debitage and a point base. The base places the site in the Transitional Archaic. After finishing the additional shovel testing, under the advisement of the THC, the CAR completed a one hundred percent surface collection of the artifacts on 41KE214 to mitigate any impacts of the proposed park road and parking area improvements and impacts from future artifact collection. Lithic material recovered from the surface consisted of 204 specimens of debitage, 2 point fragments, 7 bifaces, 3 retouched flakes, and 2 cores. The CAR, under advisement from the THC, recommends that the improvements to the existing road and the construction of the parking areas and trails proceed as proposed with the caveat that work conducted in the area of $41 \mathrm{KE} 214$ be monitored by personnel from the CAR to document any cultural features that may be exposed.

Following laboratory processing and analysis, and in consultation with both the Commissioner's Court of Kendall County and the Texas Historical Commission (THC), all sediment samples were discarded. This discard was in conformance with THC guidelines. All remaining archaeological samples collected by the CAR, along with all associated artifacts, documents, notes, and photographs, were prepared for curation according to THC guidelines and are permanently curated at the Center for Archaeological Research at the University of Texas at San Antonio. The CAR requested and was assigned a trinomial (41KE214) for the site. The TexSite records are on file at The Texas Archeological Research Laboratory (TARL). 


\section{Table of Contents:}

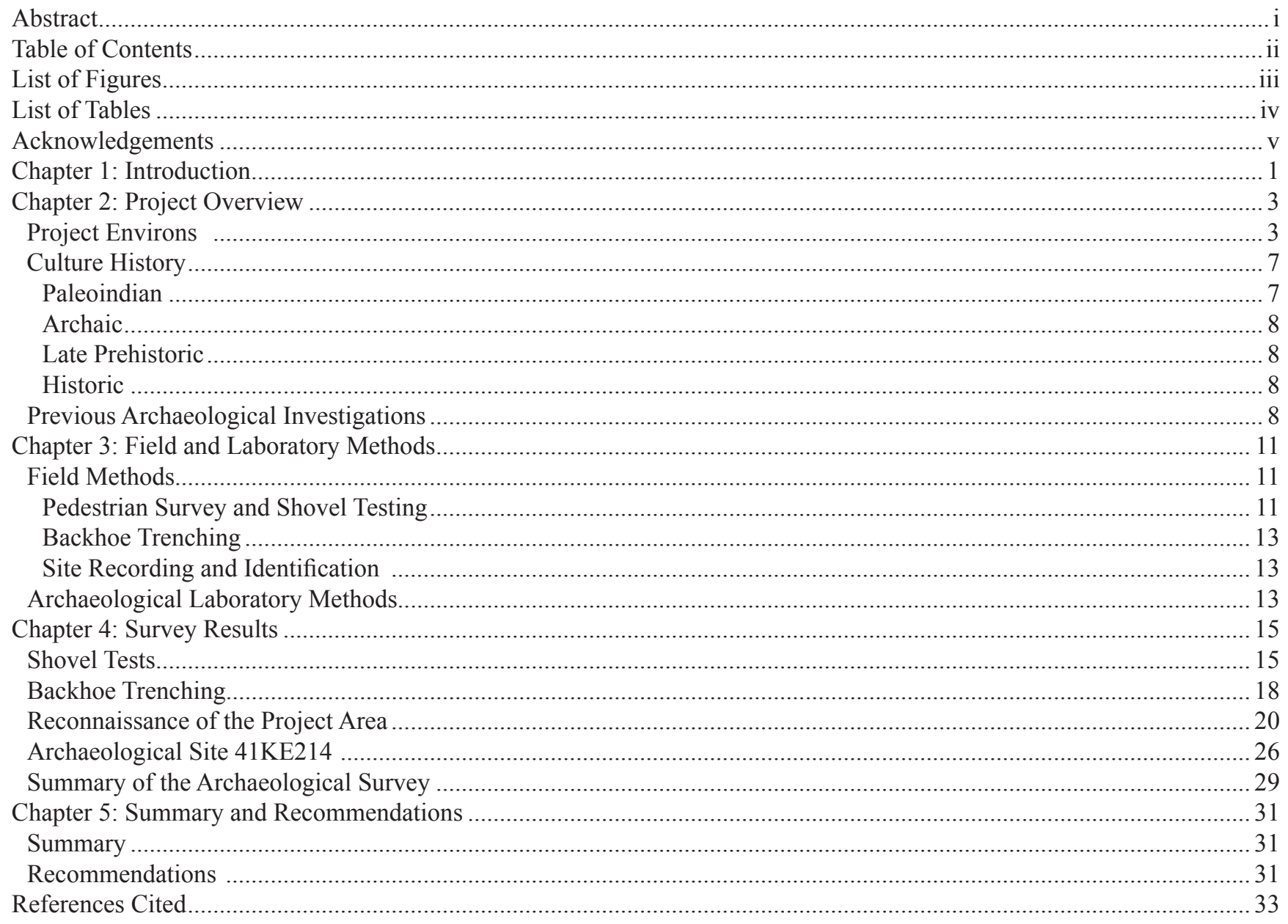

APPENDIX A: Additional Shovel Testing and Surface Collection at 41KE214 


\section{List of Figures:}

Figure 1-1. Map of Kendall County, showing location of project area........................................................................ 1

Figure 1-2. Aerial map showing preliminary plan of park road (blue) and parking areas (white).......................................2

Figure 2-1. Typical vegetation of the Edwards Plateau on the project area.................................................................... 3

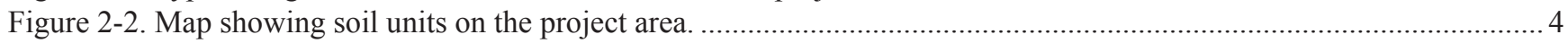

Figure 2-3. Example of the Orif-Boerne association soil unit on the project area.............................................................5

Figure 2-4. Example of the Boerne fine sandy loam soil unit on the project area. ............................................................5

Figure 2-5. Example of the Eckrant-Comfort association soil unit on the project area....................................................... 6

Figure 2-6. Example of the Eckrant-Rock outcrop association soil unit on the project area................................................ 6

Figure 2-7. Example of the Krum silty clay soil unit on the project area. ……................................................................ 7

Figure 3-1. The location of shovel tests (white) and backhoe trenches (yellow) on the project area. .................................. 12

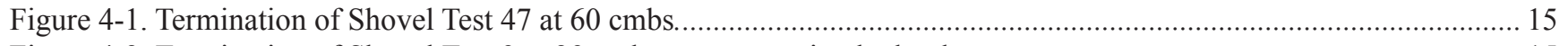

Figure 4-2. Termination of Shovel Test 9 at $29 \mathrm{cmbs}$ upon exposing bedrock. ........................................................... 15

Figure 4-3. Soil map of project area showing termination depths of shovel tests............................................................ 17

Figure 4-4. Soil colors from Level 1 (left) and Level 5 (right) of the shovel tests on a soil map of the

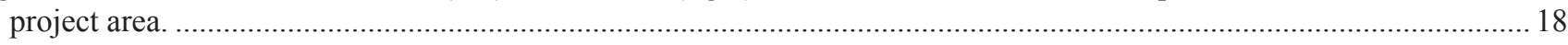

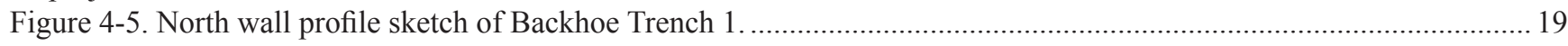

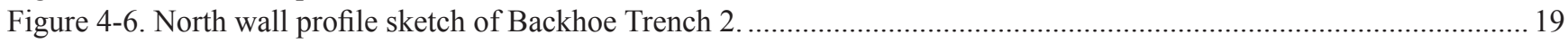

Figure 4-7. Cutbank on the project area along the south bank of the Guadalupe River.....................................................2 20

Figure 4-8. Location of isolated finds (lithic artifacts) on the project area. ....................................................................2

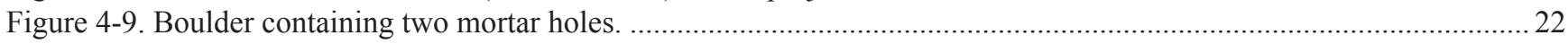

Figure 4-10. Sketch of mortar holes showing dimensions, based on measurements in the field. .....................................23

Figure 4-11. Aerial map of project area noting location of two sinkholes, one seep, and a cave. …..................................24

Figure 4-12. Sinkhole located near southern boundary of the project area (note that dimensions

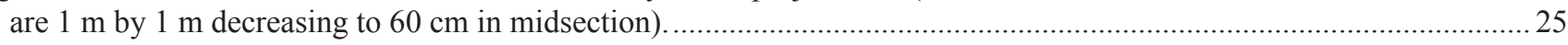

Figure 4-13. Cave located on southern portion of project area. …...............................................................................2 25

Figure 4-14. Aerial map of 41KE214 showing site boundary (blue), location of shovel tests (red),

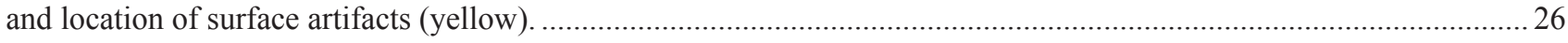

Figure 4-15. Biface located adjacent to the park road on site 41 KE214 ......................................................................2 27

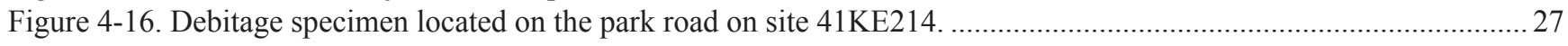

Figure 4-17. Burned rock without any staining or charcoal located in the center of the existing park

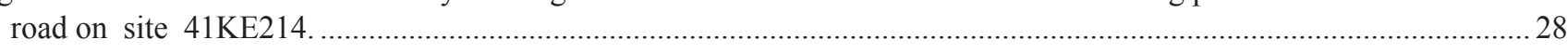

Figure 4-18. Overview of southern section of 41KE214 (note park road and vegetation on sides of road) ..........................22

Figure 4-19. Overview of northern section of 41KE214 (note sides of park road are clear).............................................29

Figure A-1. Aerial view of 41KE214 showing location of positive (blue) and negative shovel tests (red)...........................3 39

Figure A-2. Artifacts from 41KE214: a-b) retouched flakes; c-e) bifaces; f-h) projectile point fragments.......................... 40

Figure A-3. Distribution of debitage on 41KE214 showing distinct clusters of materials (1=yellow;

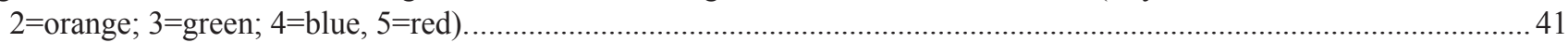

Figure A-4. Plot comparing debitage weighed by location on 41KE214 .................................................................. 42 


\section{List of Tables:}

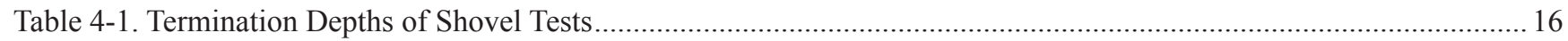

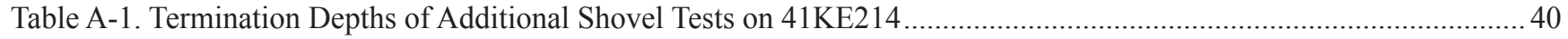

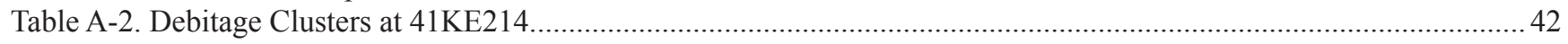




\section{Acknowledgements:}

The successful completion of this project is owed in a large part to the able and hard-working field crew. They included the following individuals from the Center for Archaeological Research: Steve Smith, Cody Miller, Lindy Martinez, Cyndi Dickey, and Kelley Denham. Thank you all. Dr. Raymond Mauldin, CAR Assistant Director, served as principal investigator on the project and provided comments on the report. Cyndi Dickey assisted with the identification of soil colors. Jennifer Thompson acted as editor. The author would also like to thank Bruce Moses and Barbara Meissner for drafting the figures and producing the final manuscript. The author thanks Richard Tobolka and Steve Lowe of Kendall County, Abel Sifuentes of Alamo Backhoe Contractors, Inc., and Debra Beene of the Texas Historic Commission for their assistance. 



\section{Chapter 1: Introduction}

The Center for Archaeological Research (CAR) of the University of Texas at San Antonio (UTSA) was contracted by the Commissioner's Court of Kendall County to conduct an intensive pedestrian archaeological survey on a 117-acre (47.35 ha) park located in south-central Kendall County, Texas. The survey, conducted in advance of proposed improvements, occurred in February 2010. The park will consist of picnic areas, trails, a park road, and a two parking areas. Road improvements, parking, and trails will be designed to minimize soil disturbance and erosion. The parking areas will be created and surfaced with caliche. Road construction will consist of widening and surfacing an existing dirt road with caliche to allow for two-way traffic. Thus, no excavation is anticipated during construction. The principal goal of the pedestrian survey was to identify and document all prehistoric and historic archaeological sites that may be impacted by the proposed improvements within the park. The archaeological survey was performed under Texas Antiquities Permit No. 5540, with Dr. Raymond Mauldin, CAR Assistant Director, serving as Principal Investigator and Cynthia Moore Munoz serving as Project Archaeologist.
1-1). The 117-acre project area is approximately 460 meters (east-west) by 1,060 meters (north-south). The proposed park facility is part of the County's Master Plan for Parks, Recreation and Open Space for Kendall County.

The archaeological survey consisted of a one hundred percent pedestrian reconnaissance of the 117-acre property with shovel testing accompanied by a linear survey with shovel testing of the approximately 0.76 mile $(1.22 \mathrm{~km})$ park road including the proposed parking areas (Figure 1-2), and backhoe trenching along the terrace of the Guadalupe River. The project area is on the Sisterdale, Texas USGS 7.5' quadrangle map. The survey included the hand excavation of 64 shovel tests and the mechanical excavation of 2 backhoe trenches.

In the process of conducting the Kendall County Park survey, one new site was identified, 41KE214, one isolated surface feature was noted, and eighteen isolated surface artifacts, including debitage, tools, one core, and burned rock were documented. The site, consisting of a surface scatter of
The land impacted by the project is owned by Kendall County, a political subdivision of the State of Texas. As such, the project has to comply with State Historic Preservation laws and specifically the mandates of the Antiquities Code of Texas. Projects receiving federal funding and/or permitting must comply with Section 106 of the National Historic Preservation Act (NHPA) of 1966. One outcome of the NHPA was the creation of the National Register of Historic Places (NRHP) and the Advisory Council of Historic Preservation. Section 106 of the NHPA stipulates that the Advisory Council must be given "a reasonable opportunity to comment" regarding the effect of any undertakings that could impact properties that may be eligible for inclusion in the NRHP. All undertakings that derive from actions funded by, permitted by, or licensed by federal agencies fall under this requirement.

The project area, located approximately 8.7 miles $(14.0 \mathrm{~km})$ northeast of Boerne, Texas, is bounded by the Guadalupe River to the north and a surface road to the south. The east and west boundaries consist of fence lines delineating private rural properties (Figure

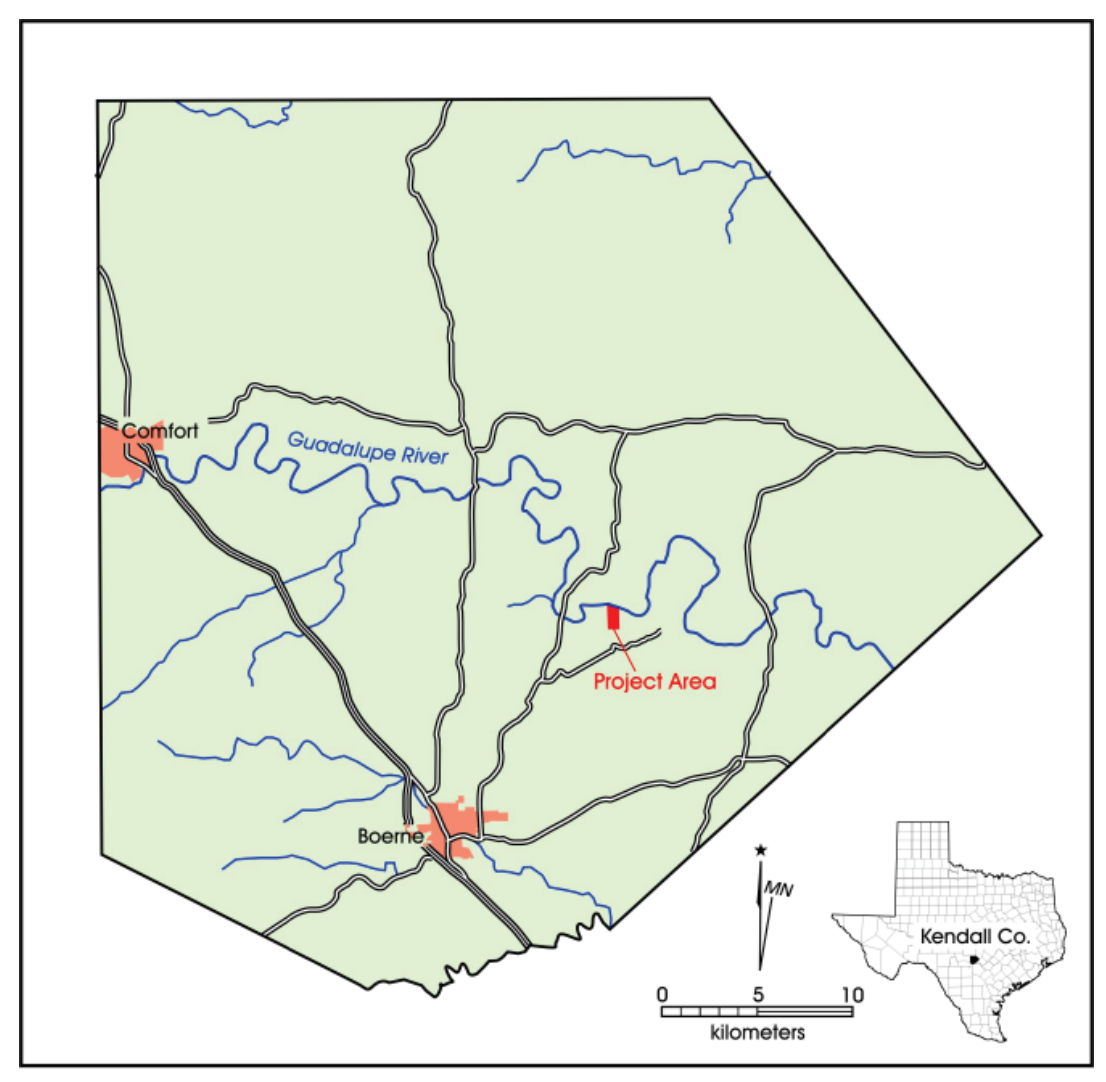

Figure 1-1. Map of Kendall County, showing location of project area. 


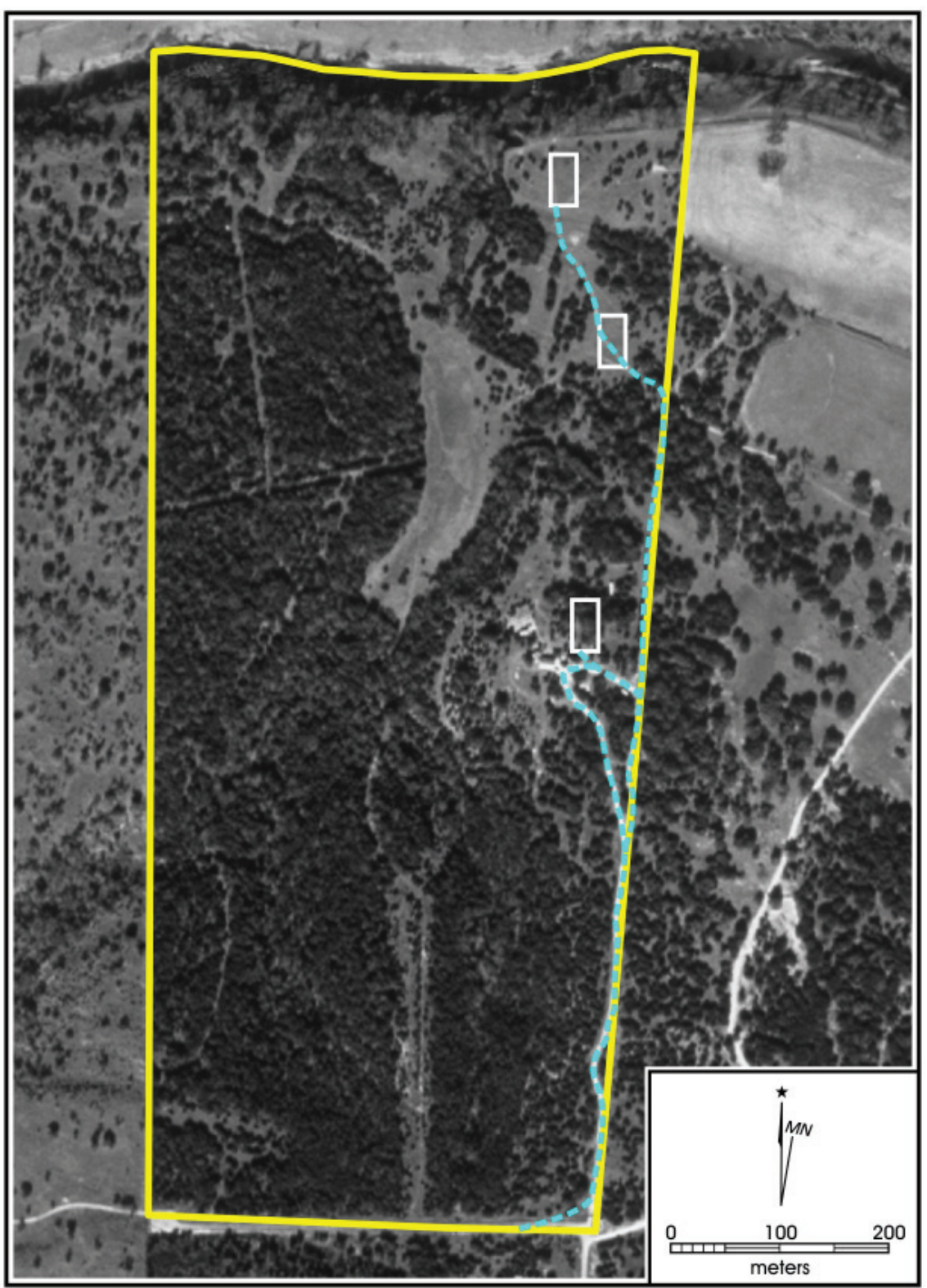

Figure 1-2. Aerial map showing preliminary plan of park road (blue) and parking areas (white).

lithic debitage, tools, and burned rock not associated with charcoal or staining, is located directly on the park road. Eleven shovel tests excavated to delineate the site were all negative. No diagnostic artifacts were noted. No features were associated with the site. Because of the lack of material depth, features, and diagnostics, the CAR recommends that the site be considered ineligible for listing on the NRHP. Upon completion of the shovel testing of site 41KE214, the Texas Historic Commission requested the excavation of additional shovel tests to confirm the extent of the site and the lack of deep deposits. The CAR excavated 22 additional shovel tests on and around 41KE214 to supplement the ones excavated previously resulting in 34 shovel tests associated with the site. Of the 34 shovel tests, 1 was positive producing two pieces of debitage and a point base. The base places the site in the Transitional Archaic. After finishing the additional shovel testing, under the advisement of the THC, the CAR completed a one hundred percent surface collection of the artifacts on $41 \mathrm{KE} 214$ to mitigate any impacts of the proposed park road and parking area improvements and impacts from future artifact collection by park visitors. Lithic material recovered from the surface consisted of 204 specimens of debitage, 2 point fragments, 7 bifaces, 3 retouched flakes, and 2 cores.

The isolated surface feature, a large boulder containing two mortar holes, is located away from the road, parking areas, and proposed picnic areas. It sits on an area of exposed bedrock. No surface artifacts were noted within a 30 meter radius of the mortar holes. Of interest, two sinkholes and one cave were documented during the pedestrian reconnaissance. The openings of all three are large and the depth of each is substantial making them potential locations of prehistoric human interments. Personnel from the CAR did not enter the sinkholes or cave due to safety concerns. The CAR recommends that the improvements to the existing road and the construction of the parking areas proceed as proposed. A monitor from the CAR must be present during work on the portion of the road crossing site 41KE214. Additionally, the CAR recommends that the cave and sinkhole openings be protected to prevent exploration and looting of potential cultural material. Recommendations will be discussed in detail in Chapter 5.

This document summarizes the results of the fieldwork and provides recommendations regarding the management of cultural resources located on the project area. This report is organized into five chapters. Chapter 2 provides a brief overview of the project area and summarizes the archaeological knowledge about the region. Chapter 3 discusses the fieldwork and laboratory methodology used during the project. The results of the archaeological survey are presented in detail in Chapter 4. Chapter 5 summarizes the work and provides recommendations for the Kendall County Park project. 


\section{Chapter 2: Project Overview}

This chapter presents a brief description of the Kendall County Park project and characterizes the project area environs and culture history. The chapter concludes with a summary of previous archaeological work conducted in the vicinity of the project area.

\section{Project Environs}

The project area, consisting of 117 acres on the Upper Guadalupe watershed in south-central Kendall County, is in the southern margins of the Edwards Plateau and includes roughly $515 \mathrm{~m}$ of river frontage, the immediately adjacent floodplain, terrace deposits, and karst uplands. Karst regions, formed by the dissolution of soluble rocks, including limestone and dolomite, typically are landscapes made up of caves and sinkholes containing large aquifers, such as the Edwards Aquifer. The Edward Plateau is made up of Cretaceous-age sandstone, shale, dolomite, and limestone deposits. During the Cretaceous Period (66-144 million years ago) shallow seas covered the plateau. As calcareous animals died and sank to the sea floor, thick layers of limestone formed which gradually built immense sedimentary rock formations (Spearing 1991). Elevations on the Edwards Plateau range from roughly $183 \mathrm{~m}$ above mean sea level (amsl) on the eastern side to roughly 610 $\mathrm{m}$ amsl on the western side. In the immediate project area (343-396 $\mathrm{m}$ amsl), the surface geology consists of Lower Cretaceous Glen Rose limestone (Barnes 1983). The plateau contains a diverse system of aquifers, springs, and rivers. Water percolates through the Lower Cretaceous limestone into the Edwards Aquifer, which lies under $67,200 \mathrm{~km} 2$ of west-central Texas. The outcomes of this process are springs, creeks, and rivers (Barker et al. 1994). The Guadalupe River emerges from the aquifer as a spring in Kerr
County. The North and South Fork Guadalupe Rivers commence in southwestern Kerr County, meet at the city of Hunt, then continue across 14 counties over a 250 mile (402 km) course to the Gulf of Mexico (Houk et al. 2008).

The section of the Guadalupe River on the Edwards Plateau meanders through the Balconian biotic province (Blair 1950). The project area is located near the southeastern edge of the province. The province is characterized by a general vegetation region known as the JuniperOak-Mesquite Savanna (Arbingast 1976). The project area supports a diverse assemblage of flora (Figure 2-1) including two vegetation types, Live Oak-Ashe Juniper Park (found primarily on gently rolling uplands and ridge tops) and Live Oak-Ashe Juniper Woods (found mainly on shallow limestone soils on hills and escarpments), as defined by the Texas Parks and Wildlife (TPWD 2010). Plants found on the project area from both types include Texas oak (Quercus texana), shin oak (Quercus sinuate var. breviloba), cedar elm (Ulmus crassifolia), saw greenbriar (Smilax bona-nox), Texas wintergrass (Stipa leucotricha), little bluestem (Schizachyrium scoparium

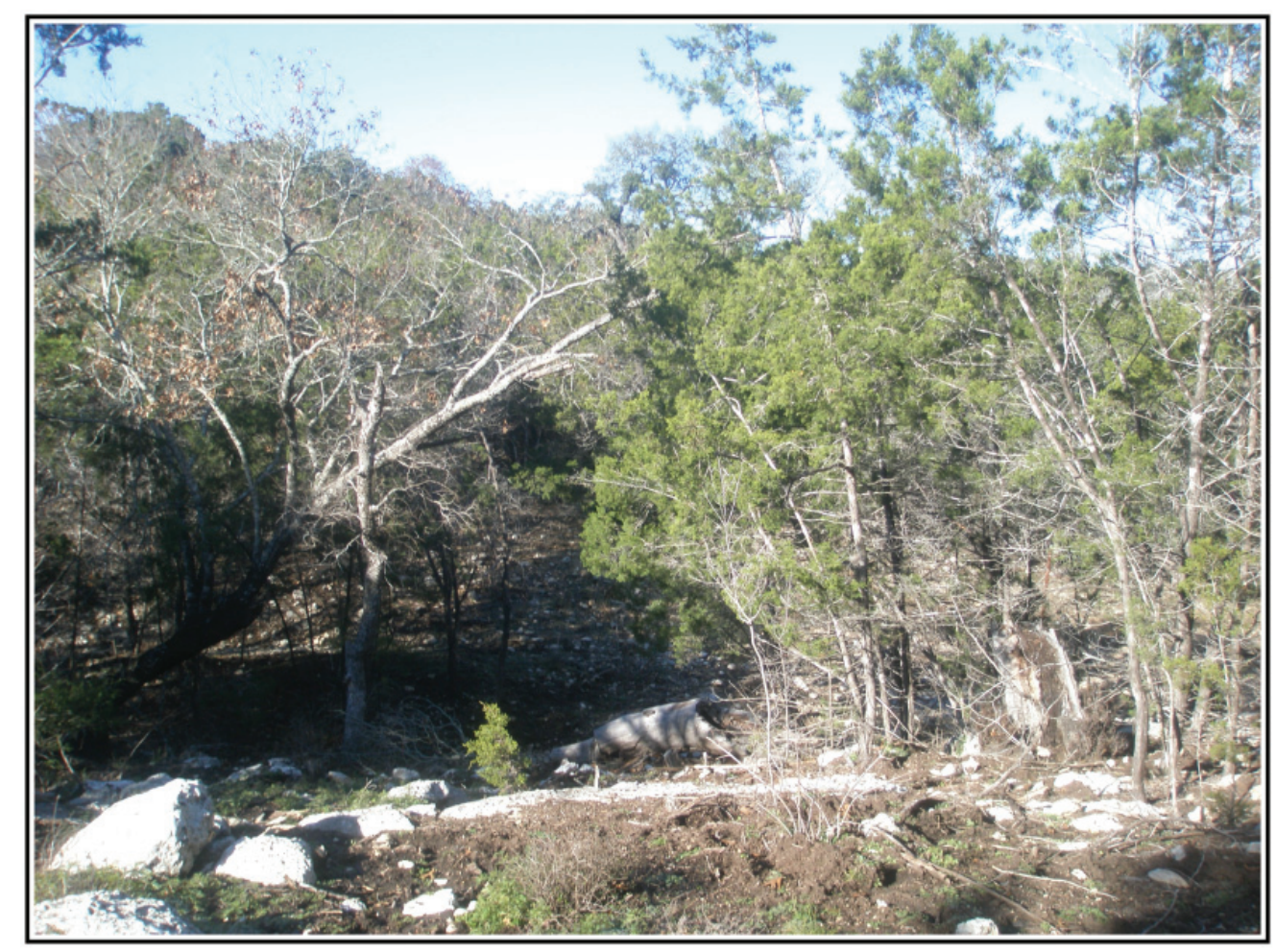

Figure 2-1. Typical vegetation of the Edwards Plateau on the project area. 
var. frequens), curly mesquite (Hilaria belangeri), Texas grama (Bouteloua rigidiseta), cedar sedge (Carex planostachys), and mat euphorbia (Euphorbia serpens). Plants commonly associated with Live OakAshe Juniper Park include, netleaf hackberry (Celtis reticulata), flameleaf sumac (Rhus lanceolata), agarito (Berberis trifoliolata), Mexican persimmon (Diospyrost texana), Texas prickly pear (Opuntia lindheimeri), kidneywood (Eysenhardtia texana), Halls panicum (Panicum hallii), purple three-awn (Aristida purpurea), hairy tridens (Tridens hirsuta), two-leaved senna (Cassia roemeriana), and rabbit tobacco (Evax prolifera). Types associated with Live Oak-Ashe Juniper Woods include evergreen sumac (Rhus virens), escarpment cherry (Prunus serotina var. eximia), mescal bean (Sophora secundiflora), poison oak (Rhus toxicodendron), twistleaf yucca (Yucca rupicola), elbowbush (Forestiera pubescens), Neally grama (Bouteloua uniflora), meadow dropseed (Sporobolus asper var. hookeri), pellitory nosebum (Tragia ramosa), spreading sida (Sida filicaulis), and woodsorrel (Oxalis spp.; TPWD 2010).

Fifty-seven species of mammals, one turtle, sixteen species of lizard, thirty-six species of snakes, and fifteen frog and toad species have been documented on the Balconian province (Blair 1950). Extant mammals commonly found in the area include whitetailed deer (Odocoileus virginianus), bobcat (Lynx rufus), coyote (Canis latrans), gray fox (Urocyon cinereoargenteous), opossum (Didelphis virginiana), nine-banded armadillo (Dasypus novemcinctus), black-tailed jackrabbit (Lepus californicus), raccoon (Procyon lotor), and deer mouse (Peromyscus maniculatis). Bison (Bison bison), mountain lion (Felis concolor), and black bear (Ursus americanus) were in the area prehistorically (Davis and Schmidly 1994). The Balconian province is the main breeding area for the golden-cheeked warbler (Dendroica chrysoparia) and the black-capped vireo (Vireo atricapillus; Kutac 1994).

Climate in this general area is classified as humid subtropical with hot, humid summers and mild, dry winters. Rainfall averages approximately 32 inches per year. The average minimum and maximum temperature for the region is $35^{\circ} \mathrm{F}$ in January and $94^{\circ} \mathrm{F}$ in July, respectively. The growing season averages 231 days annually (Handbook of Texas Online 2010).

The project area consists of five soil units: Orif-Boerne association, Boerne fine sandy loam, Eckrant-Comfort association, Eckrant-Rock outcrop association, and Krum

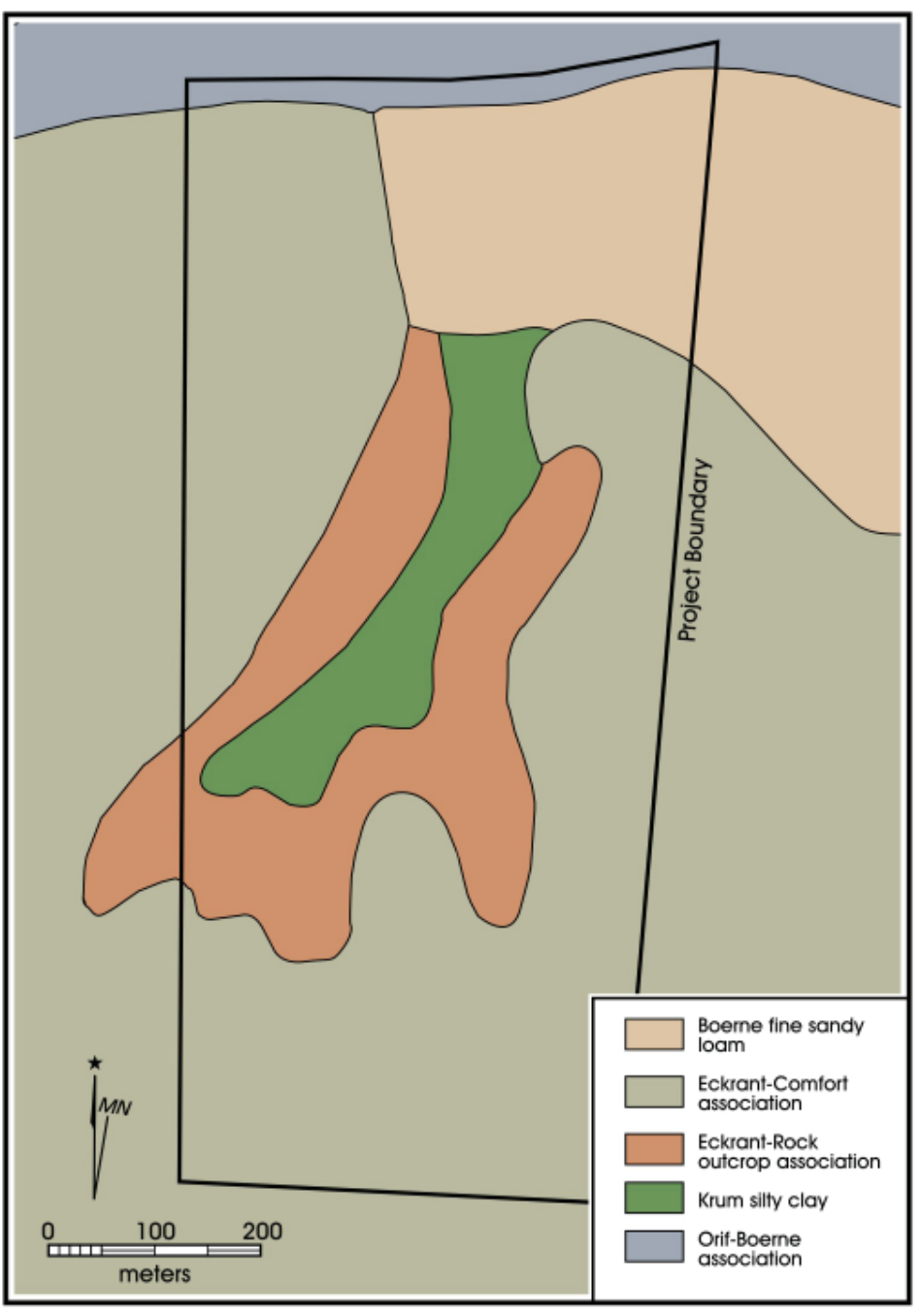

Figure 2-2. Map showing soil units on the project area.

silty clay (Figure 2-2). The soils abutting the Guadalupe River make up $2 \%$ of the project area (Figure 2-3) and are described as Orif-Boerne association. This association consists of loamy and gravelly soils on flood plains. These soils are long, narrow, and parallel to the channels of major perennial streams. They are gently undulating and frequently flooded. Orif soils consist of coarse sand from 102 to $203 \mathrm{~cm}$ below surface $(\mathrm{cmbs})$ overlain by $61 \mathrm{~cm}$ of extremely gravelly sand which are overlain by $41 \mathrm{~cm}$ of gravelly sandy loam. Boerne soils consist of $20 \mathrm{~cm}$ of fine sandy loam covering $137 \mathrm{~cm}$ of loam (Dittemore and Hensell 1981; Soil Survey Staff 2010).

Two types of soil are upslope from the Orif-Boerne association covering $14 \%$ and $58 \%$ of the project area; Boerne fine sandy loam (Figure 2-4) and Eckrant-Comfort association (Figure 2-5), respectively. The former are described as occasionally flooded soils located on flood plains and stream terraces. The soil consists of $20 \mathrm{~cm}$ of 


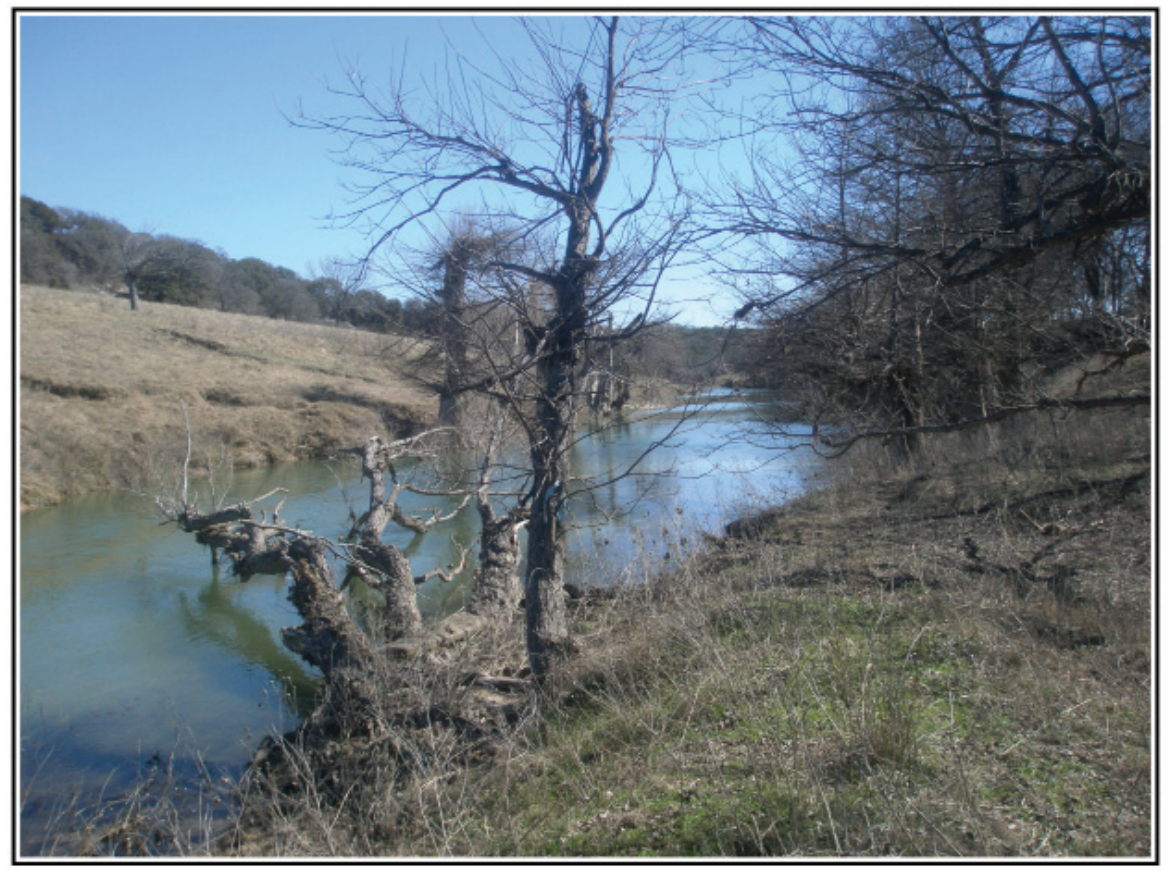

Figure 2-3. Example of the Orif-Boerne association soil unit on the project area.

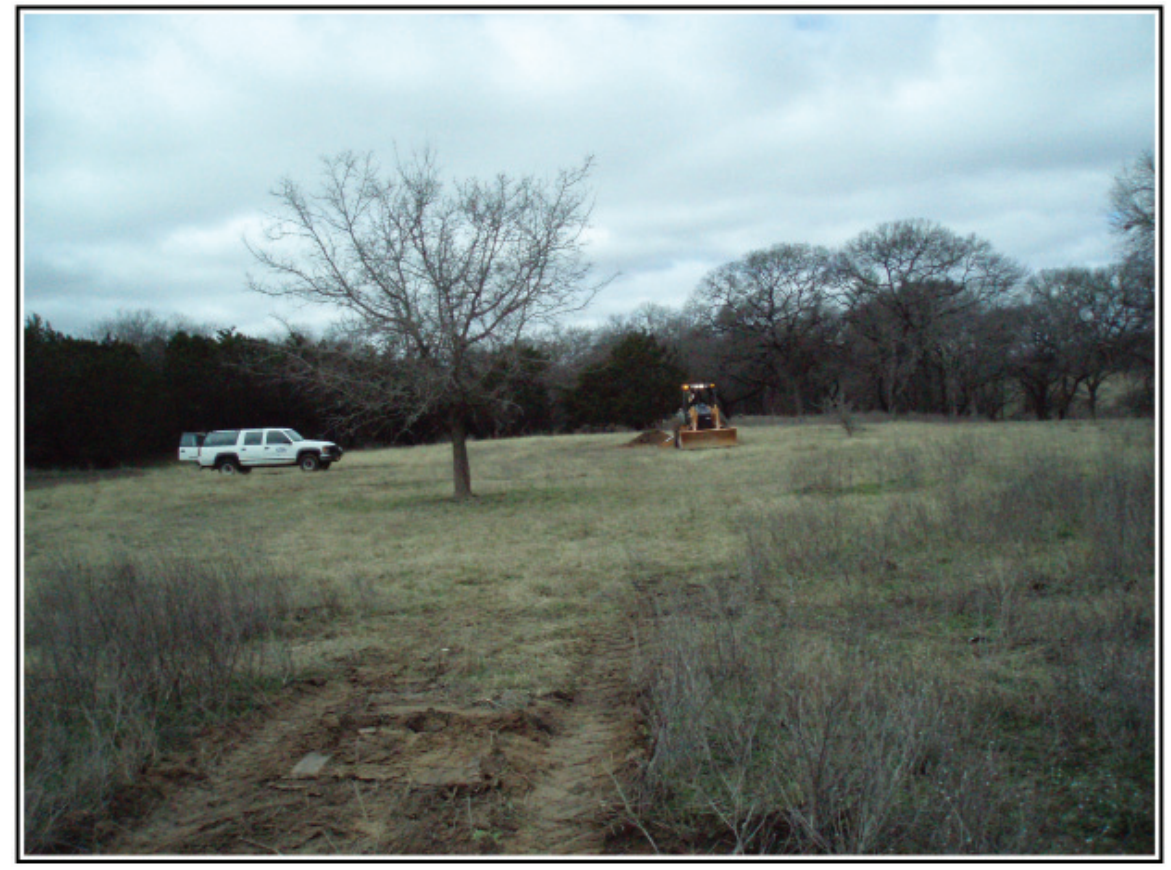

Figure 2-4. Example of the Boerne fine sandy loam soil unit on the project area.

fine sandy loam over $97 \mathrm{~cm}$ of pale brown loam resting on $41 \mathrm{~cm}$ of light yellowish brown loam. Eckrant-Comfort association is made up of gently undulating, shallow, cobbly and stony soils on broad upland hilltops. Typically, Eckrant soils have a surface layer of stony clay roughly 13 $\mathrm{cm}$ thick resting on $89 \mathrm{~cm}$ of fractured limestone bedrock. Comfort soils consist of $13 \mathrm{~cm}$ of dark grayish brown stony clay on top of $30 \mathrm{~cm}$ of dark reddish gray stony clay over $58 \mathrm{~cm}$ of limestone bedrock (Dittemore and Hensell 1981; Soil Survey Staff 2010). 
Approximately $18 \%$ of the project area, located in the midsection of the property, contains soils classified as Eckrant-Rock outcrop association (Figure 2-6). This association is made up of rock outcrops and very shallow, cobbly and stony, clayey soils. The soils are found on the sides of narrow, long limestone hills that are side slopes of secondary drainages. Eckrant soils tend to have a surface layer of $13 \mathrm{~cm}$ of very stony clay over $89 \mathrm{~cm}$ of fractured limestone bedrock. Rock outcrops consist of $203 \mathrm{~cm}$ of bedrock. On the project area, the Eckrant-Rock outcrop association wraps around an area of Krum silty clay. This deep, gently sloping soil, representing $8 \%$ of the

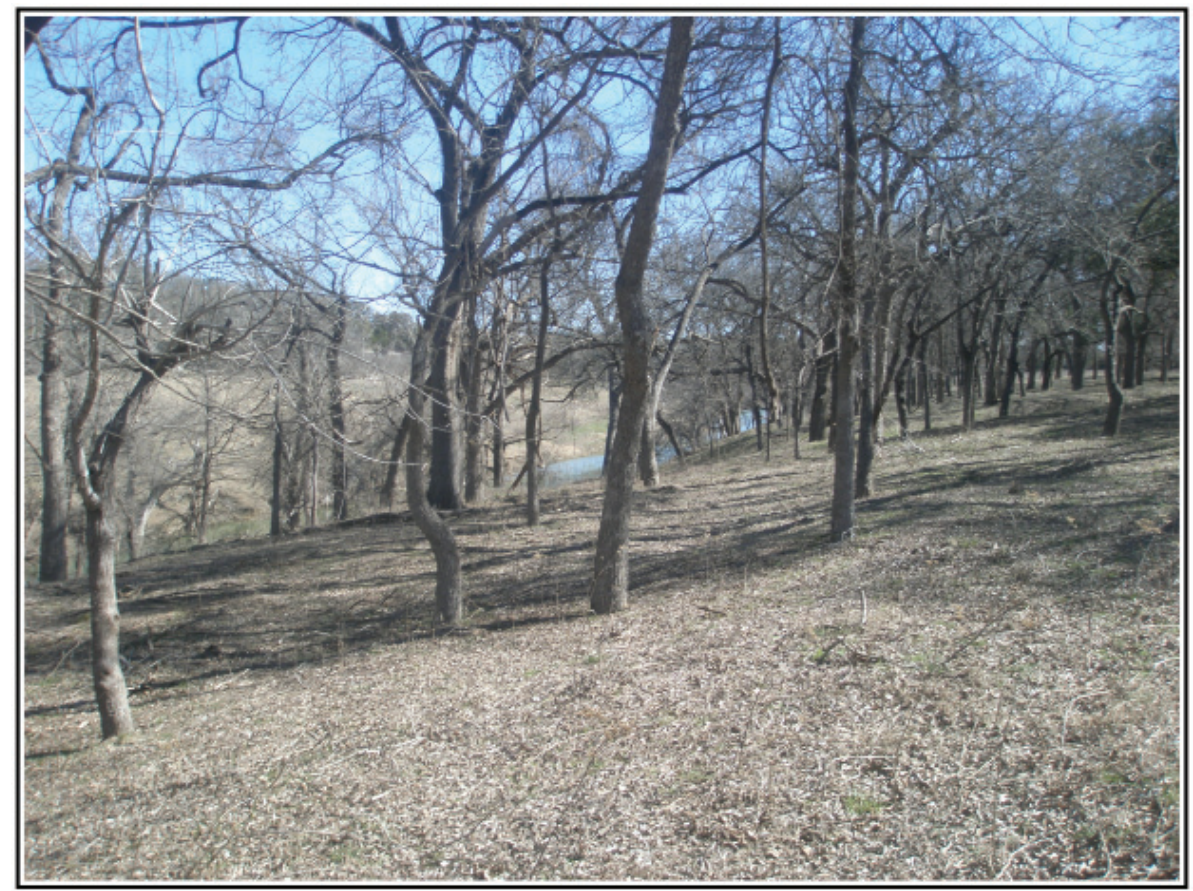

Figure 2-5. Example of the Eckrant-Comfort association soil unit on the project area.

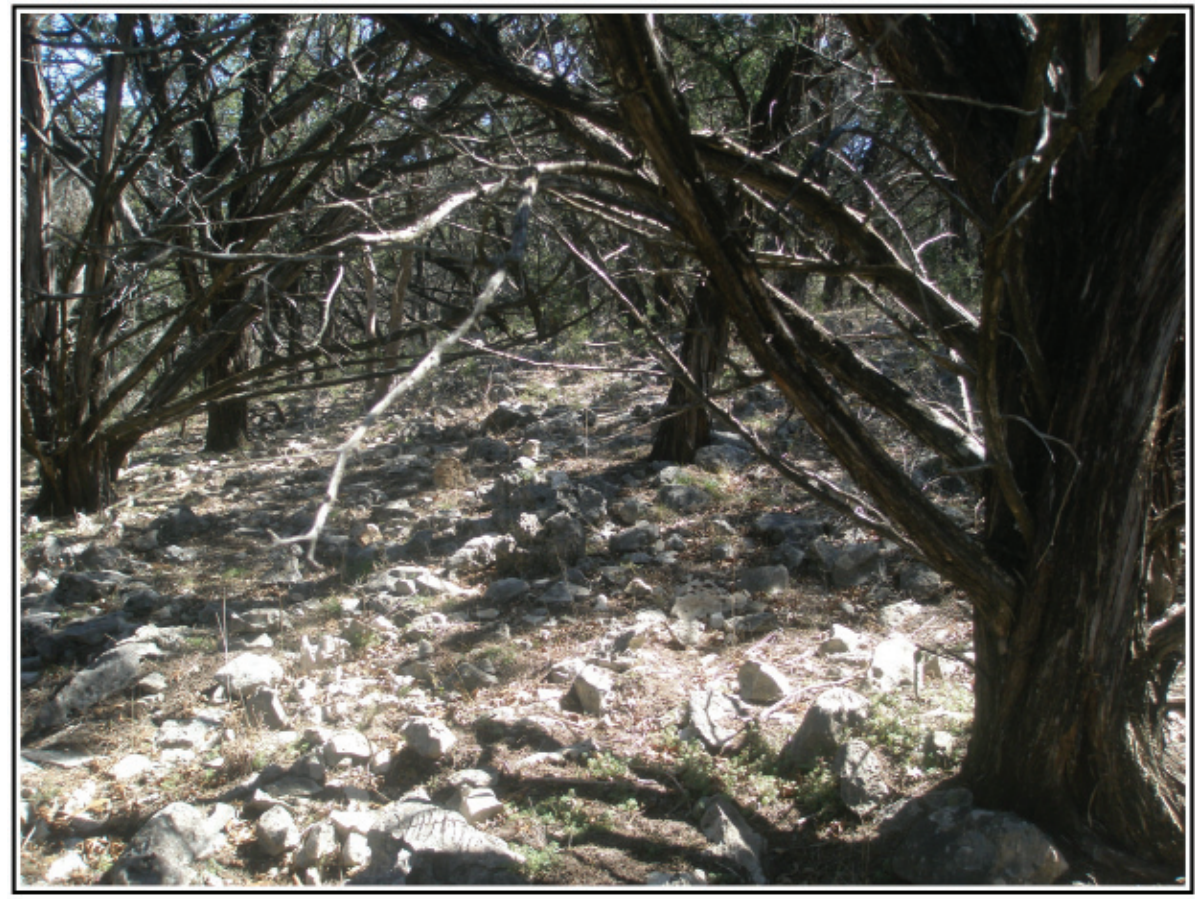

Figure 2-6. Example of the Eckrant-Rock outcrop association soil unit on the project area. 
project area (Figure 2-7), is found on the foot slopes of limestone hills. Krum silty clay tends to contain U-shaped, intermittent, spring-fed drainage channels. Typically, the soil consists of $41 \mathrm{~cm}$ of dark grayish brown silty clay over $53 \mathrm{~cm}$ of brown silty clay resting on $38 \mathrm{~cm}$ of light yellowish brown silty clay (Dittemore and Hensell 1981; Soil Survey Staff 2010).

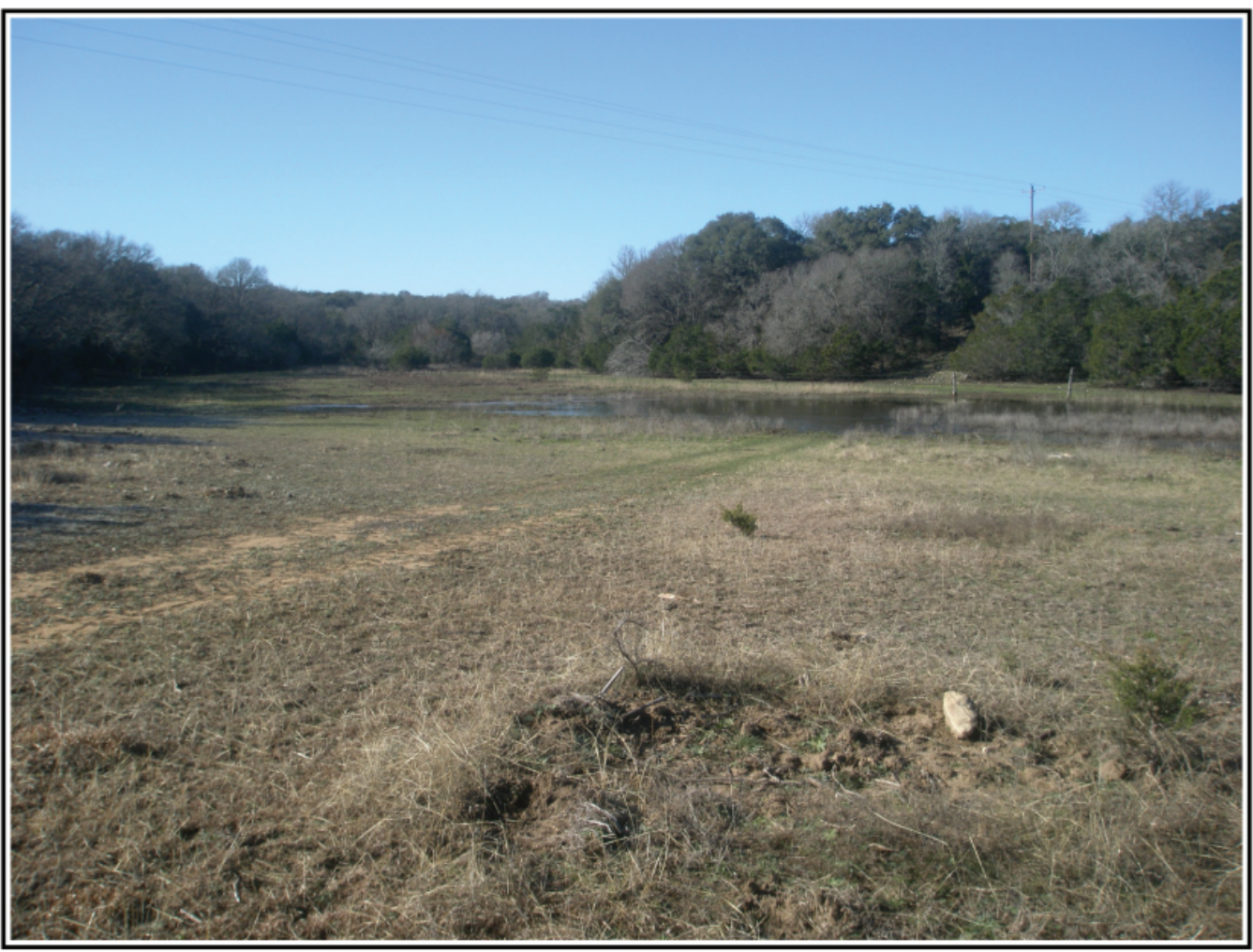

Figure 2-7. Example of the Krum silty clay soil unit on the project area.

\section{Culture History}

In Central Texas, researchers have been able to document a long prehistoric sequence that can be broken down into four major time periods: Paleoindian, Archaic, Late Prehistoric, and Historic (Black 1989; Collins 1995; Johnson and Goode 1994; Prewitt 1981). These periods are further divided into sub-periods that are based on particular subsistence strategies and material culture. A brief description of each period follows to illustrate the archaeological potential of the region.

\section{Paleoindian}

The Paleoindian period (11,500-8800 BP) is divided into early and late sub-periods, each characterized by particular projectile point styles and subsistence patterns
(Collins 1995). The period begins at the close of the Pleistocene with the earliest evidence of humans in the Central Texas region. Clovis and Folsom point types, and bifacial Clear Fork tools and finely flaked end scrapers characterize the early Paleoindian period (Black 1989). The first stemmed points (i.e., Wilson), as opposed to lanceolate points (i.e., Angostura and Golondrina), begin

to appear during the late Paleoindian period. In the past, Paleoindian populations have generally been characterized as huntergatherers ranging over wide areas in pursuit of now extinct megafauna, such as mammoth and Bison antiquus. However, research from the Wilson-Leonard site in Central Texas (Collins 1998) and other perspectives on Paleoindian adaptations (Tankersley and Isaac 1990) indicate that the diet of these early inhabitants may have been much broader. Although exploiting Late Pleistocene megafauna may have constituted a part of Paleoindian subsistence, these peoples are perhaps better characterized as more generalized hunter-gatherers, exploiting a wide variety of plants and animals including large herbivores like deer, antelope, and bison and small animals such as turtles, alligators, rabbit, and raccoons (Collins 1995; Nickels 2000).

In Central Texas, many of the sites containing Paleoindian cultural materials are found on high terraces, valley margins, and upland locations (Black 1989). This seems to fit with a broader pattern of Paleoindian site distributions where sites are located on landforms providing views of the surrounding landscape, are centered on critical resource zones, or are found in highly productive resource areas (Tankersley and Isaac 1990). Paleoindian artifacts are commonly recovered as isolated finds or from lithic scatters lacking good stratigraphic 
context including kill, quarry, cache, camp, ritual and burial sites (Collins 1995).

\section{Archaic}

The Archaic period ( $8800-1200 \mathrm{BP}$ ) is identified as a period of intensification of hunting and gathering and a move toward greater exploitation of local resources. As a result, a broadening of the material culture is evident, including the "extensive use of heated rock" in cooking (Collins 1995:383). Food processing technologies appeared to have broadened as features such as hearths, ovens, and middens increase in frequency during this time (Black and McGraw 1985). During this period, large cemeteries were formed indicating an increasing population and the subsequent establishment of territories (Black and McGraw 1985).

The Early, Middle, and Late Archaic subperiods correspond with changes in climatic conditions and resource availability and are distinguished by differences in diagnostic projectile points (Collins 1995; Johnson and Goode 1994). During the Early Archaic (8800-5000 BP), a variety of Early Corner-Notched (Uvalde, Martindale, Baker) and then later Early Basal-Notched (Bell, Andice) points appeared across Central Texas. Early Archaic sites are often recorded on river terraces or on hills overlooking valleys (Hester 1995:439). A new set of temporally diagnostic artifacts are associated with the onset of the Middle Archaic (5000-2400 BP) including Pedernales, Langtry, Kinney, and Bulverde point types as well as triangular bifaces and tubular stone pipes (Black 1989; Hester 1995). In addition to the upland setting, Middle Archaic campsites are commonly located on floodplains, low terraces, and natural levees. The Late Archaic (24001200 BP) is characterized by the presence of Shumla, Montell, and Marcos point types and a diminution of projectile point sites near the end of the subperiod (i.e. Ensor, Ellis, Figueroa). Late Archaic sites are usually located near modern stream channels and occur in all topographic settings (Black 1989; Hester 1995).

\section{Late Prehistoric}

The Late Prehistoric period (1200-350 BP) in Central Texas marks a distinctive shift from the use of the atlatl and dart to the use of the bow and arrow (Black 1989; Collins 1995; Hester 1995). The Late Prehistoric is subdivided into early and late sub-periods termed Austin and Toyah Phases, respectively. Temporal diagnostics including Scallorn and Edwards arrow points define the Austin Phase (1200-650 BP, Prewitt 1981). It appears that the use of burned rock middens may have reached its peak during this phase (Black and Creel 1997). The subsequent Toyah
Phase spans 650-350 BP and includes the first occurrence of pottery in South Texas (Black 1989). Characteristic artifacts of this phase include Perdiz and Cliffton arrow points (Black 1986). Material culture associated with the Late Prehistoric period points to increasing complexity in subsistence patterns and to very large prehistoric populations (Black 1989; Collins 1995).

\section{Historic}

The Historic period in Texas begins with the arrival of Europeans. Although the Historic period theoretically begins in Texas with the shipwreck of the Narvaez expedition along the Texas coast in 1528, the majority of the inhabitants of Texas were Native Americans until the late eighteenth century. From AD 1550 to the late 1600s, European forays into South and Central Texas were infrequent. René Robert Cavelier, Sieur de La Salle, established a French settlement, Fort St. Louis, along Matagorda Bay on the Texas coast in 1685. Hunger, disease, and escalating hostilities between the French and the Karankawas, subsequently destroyed the colony (Foster 1998). The first Europeans settled in the region in early AD 1700 (Taylor 1996). The southward incursion of the Comanche and Apache and the northward expansion of Spanish influence led to the displacement of many of the area's indigenous groups. Decimated by disease brought by Europeans, many of the remaining groups sought refuge in the numerous Spanish missions established early in the eighteenth century. The move to the missions significantly impacted the hunter-gatherer way of life and the material culture. Artifacts from the Historic period reflect European influences and include metal, glass, and ceramics along with pre-Hispanic Goliad wares and lithic arrow points, tools, and gunflints (Taylor 1996).

\section{Previous Archaeological Investigations}

A background literature review revealed an abundance of recorded archaeological sites in Kendall County including, 2 Paleoindian, 44 Archaic, 4 Late Prehistoric, 150 unknown Prehistoric, and 13 Historic period sites (Texas Historical Commission 2010). Although no previously recorded sites are located on the project area, three sites, all on private residential properties, are located within a $2 \mathrm{~km}$ radius of the project area. Two of the sites, 41KE197 and 41KE202 contain burned rock middens. The third, 41KE56, is documented as a knapping site and probable campsite.

Site 41KE56, documented in 1975, is approximately $1,140 \mathrm{~m}$ northwest of the project area and roughly $240 \mathrm{~m}$ north of the Guadalupe River. The site was recorded as a probable campsite with evidence of knapping. Although no 
subsurface testing was noted, surface artifacts, including lithic debitage, blades, one core, arrow point fragments, Perdiz and Scallorn arrow points, were collected (Texas Historical Commission 2010).

Located on the property immediately adjacent to the project area (approximately $610 \mathrm{~m}$ to the east), 41KE202 was documented by the THC Steward in 2008 as a burned rock midden site (Texas Historical Commission 2010). The site is approximately $750 \mathrm{~m}$ south of the Guadalupe
River. The midden measured $13 \mathrm{~m}$ by $10 \mathrm{~m}$ by $60 \mathrm{~cm}$ thick. The excavation of one test unit $(1 \mathrm{~m}$ by $1 \mathrm{~m})$ uncovered lithic debitage, a biface, snails, one mussel shell, and burned rock. The property owner has a large collection of projectile points from the surface but the types are not documented (Texas Historical Commission 2010). Another burned rock midden site, 41KE197, is located approximately $2,320 \mathrm{~m}$ northeast of the project area and 170 m east of the Guadalupe River. No subsurface testing was documented but lithic debitage was noted on the surface (Texas Historical Commission 2010). 



\section{Chapter 3: Field and Laboratory Methods}

As part of the archaeological services provided to the Commissioner's Court of Kendall County, and in accordance with the THC guidelines, the CAR was contracted to conduct the following fieldwork: 1) complete an intensive pedestrian survey of 100 percent of the 117 acre property accompanied by shovel testing; 2) augment the survey with mechanically excavated backhoe trenches to investigate any deposits on the Guadalupe River terrace that could not be effectively explored using shovel testing; 3 ) document any newly discovered archaeological sites; and 4) make recommendations regarding the NRHP and State Archeological Landmark (SAL) eligibility of newly documented sites. This chapter presents the field and laboratory methods used during the archaeological investigations of the Kendall County Park project.

\section{Field Methods}

The project area consists of an approximately 0.76 mile park road and 117 acres of largely undeveloped property. The property contains a three bedroom, one bath house of approximately 1,200 square feet, a couple of storage sheds, and a small modern corral. The area includes active channel, floodplain, and terraces adjacent to the Guadalupe River as well as upland karst formations. A preliminary assessment of the project area indicated that although much of the survey area consists of exposed bedrock, the terrace adjacent to the river may consist of deep sediment deposits deemed high probability areas. A combination of methods were used during the survey including pedestrian surface reconnaissance, shovel testing, backhoe trenching, and profile documentation of large existing cutbanks near the river.

\section{Pedestrian Survey and Shovel Testing}

The archaeological investigation of the park road consisted of an intensive pedestrian survey accompanied by shovel testing. Based on the road length (approximately 0.76 miles), excavation required to fulfill the THC minimum survey standards for linear projects less than 30 meters wide was a minimum of 12 shovel tests (STs), at a density of 16 STs per mile. Shovel test locations were evenly distributed along the road and on areas designated as probable parking areas. This resulted in 12 locations. To fulfill THC minimum survey standards for non-linear properties of 101 to 200 acres ( 1 shovel test per 3 acres) an additional 38 shovel tests were distributed across the remaining 114 acres. UTM coordinates for these 50 locations were determined and uploaded into Trimble
Geo XT GPS units prior to the CAR's commencement of fieldwork. Shovel tests were located in the field using the GPS map feature. No shovel tests were excavated in areas exceeding 20 percent slopes due to the likely secondary depositional context of such materials. If a predetermined location fell on a slope, the project archaeologist determined a new location for the shovel test. The location of every shovel test was recorded with Trimble Geo XT GPS units. Upon completion of the project area survey, the project archaeologist made the decision to excavate three additional shovel tests (STs 54, 55, and 56) along the western terrace adjacent to the Guadalupe River and one additional test north of an inundated bog in the northcentral area of the site (ST 57).

Shovel tests were $30 \mathrm{~cm}$ in diameter and when possible extended to a depth of $60 \mathrm{~cm}$ below surface $(\mathrm{cmbs})$. They were excavated in $10 \mathrm{~cm}$ increments and all soil from each level was screened through 1/4-inch hardware cloth. All encountered artifacts were recovered with appropriate provenience for laboratory processing, analysis, and curation. A 2-x-3 mm bag of soil was recovered from each level. A shovel test form was completed for every excavated shovel test. Data collected from each shovel test included the final excavation depth, a tally of all materials recovered from each $10 \mathrm{~cm}$ level, and a brief soil description (texture, consistency, and inclusions). Any additional observations considered pertinent were included as comments on the standard shovel test excavation form.

The pedestrian survey of the park road revealed a surface scatter of lithic artifacts on and immediately adjacent to the road in the vicinity of a negative shovel test (ST 10). Ten additional shovel tests, eight placed on the apparent edges of the scatter and two placed within the scatter, were excavated to determine the depth of the artifacts and to delineate the boundary of the cultural material concentration. None of the additional tests was positive. The lithic scatter will be discussed in Chapter 4. Overall, the pedestrian survey of the park road and project area resulted in the hand excavation of 64 shovel tests (Figure 3-1).

In addition to the shovel testing, the survey consisted of a 100 percent pedestrian reconnaissance of the 117 acres of the property area. The CAR field crew traversed the project area along east-west transects, spaced 30 meters apart, using aerial photographs and hand-held compasses. This resulted in 32 transects. Surface features and artifacts were noted and recorded with Trimble Geo XT GPS units. 


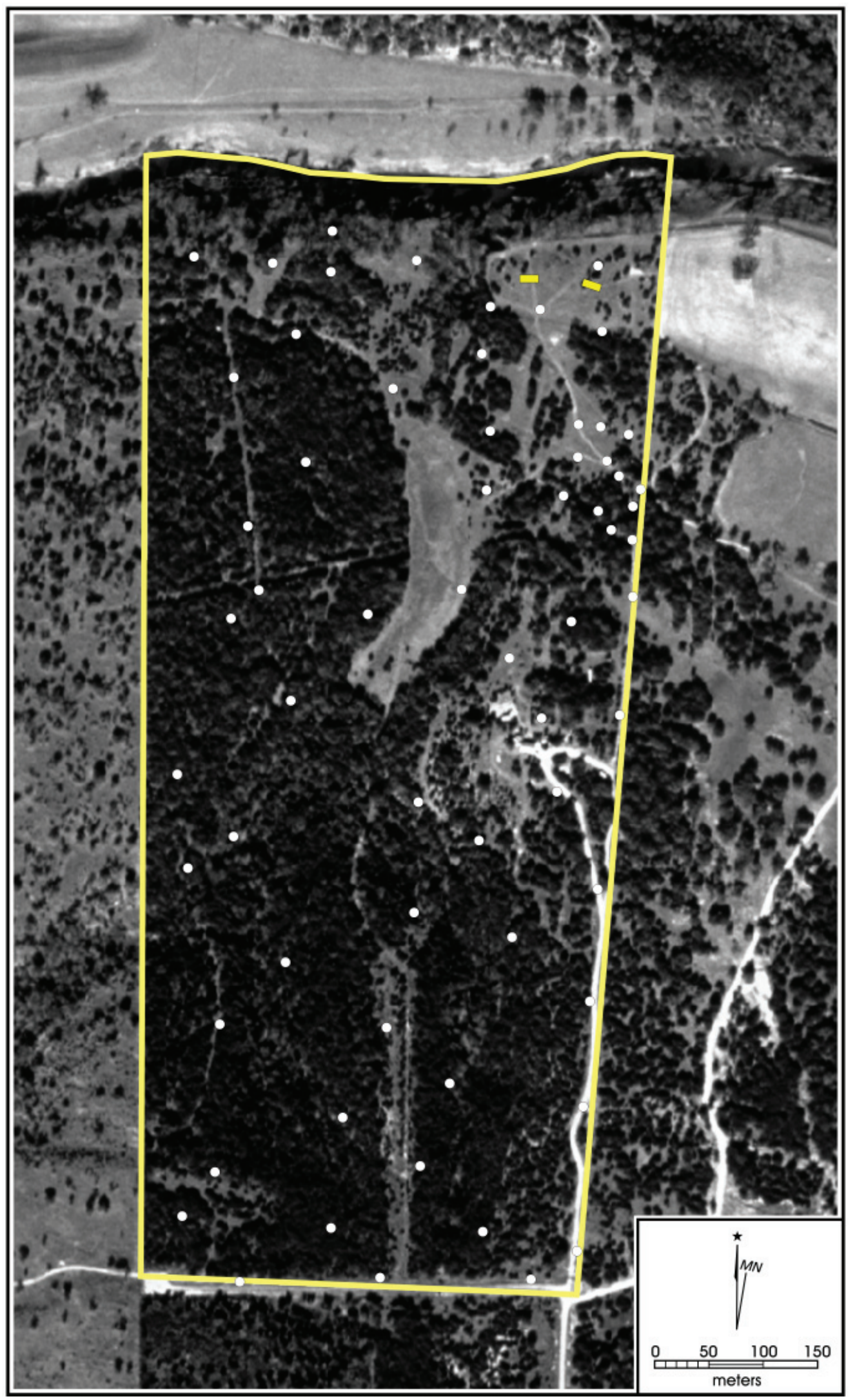

Figure 3-1. The location of shovel tests (white) and backhoe trenches (yellow) on the project area. 
All surface artifacts $(\mathrm{n}=18)$ not associated with a site were recorded as isolated finds.

\section{Backhoe Trenching}

Because of the high potential for deeply buried intact paleosols and cultural material in terraces adjacent to waterways, the archaeological investigation was accompanied by the mechanical excavation of two backhoe trenches and profile documentation of a large existing cutbank near the Guadalupe River. The backhoe trenches were excavated to expose stratigraphic profiles and potential features. They were positioned along the northern portion of the project area on the eastern terrace immediately adjacent to the Guadalupe River (see Figure 3-1). To comply with the Minimum Survey Standards as defined by the THC, the backhoe trenches were approximately one meter wide, three to five meters in length and 1.5 meters deep. After the excavation of each backhoe trench, the project archaeologist entered the trench to examine the stratigraphy and artifact density associated with the trench walls. Any discrete, potentially intact prehistoric features or deposits that were detected in the mechanically excavated backhoe trenches were recorded (i.e., profiled, photographed, scaled drawing). The backhoe trenches were excavated in full compliance with Occupational Safety and Health Administration (OSHA) standards for protection of employees in excavations (29CFR1926.652). No matrix removed via mechanical means was screened, but sediments were inspected for artifacts upon excavation.

\section{Site Recording and Identification}

For the purposes of this survey, newly encountered archaeological sites were defined as locations containing a certain number of cultural materials or features that are at least 50 years old within a given area. The definition of a site used for this project was as follows: (1) Five or more surface artifacts within a 15 meter radius (ca. $706.9 \mathrm{~m} 2$ ), or (2) a single cultural feature, such as a hearth, observed on surface or exposed in shovel testing or backhoe trenching, or (3) a positive shovel test or backhoe trench containing at least three artifacts within any given $10 \mathrm{~cm}$ level, or (4) a positive shovel test or backhoe trench containing at least five total artifacts, or (5) two positive shovel tests located within 30 meters of each other.

If cultural materials meeting the minimum criteria for an archaeological site were encountered in a shovel test or on the surface, a minimum of six shovel tests were excavated at close intervals to define the extent of the distribution. The site boundaries were then plotted on aerial photographs and a topographic quadrangle map and location data was collected with a GPS unit. The location of any cultural features, surface artifact densities, and any temporally diagnostic artifacts were plotted with the GPS. Digital photographs were taken of each site and Texas Site Forms were prepared for all new sites. Artifacts encountered that did not meet the minimum requirements for a site were treated as isolated finds. These artifacts were recorded with a GPS unit and their locations were plotted on the maps and aerials. Because no diagnostic artifacts were documented on the surface or uncovered in shovel tests or in backhoe trenches, no artifacts were collected.

\section{Archaeological Laboratory Methods}

Cultural materials and records obtained and/or generated during the project were prepared in accordance with federal regulation 36 CFR part 79, and THC requirements for State Held-in-Trust collections. Additionally, the materials were curated in accordance with current guidelines of TARL. Digital photographs were printed on acid-free paper and labeled with archivally appropriate materials and placed in archival-quality sleeves. All field forms were completed with pencil. Field notes, forms, photographs, and drawings were printed on acidfree paper and placed in archival folders. A copy of this survey report and all computer disks pertaining to the investigations were stored in an archival box and curated with the field notes and documents. Following laboratory processing and analysis, and in consultation with both the Commissioner's Court of Kendall County and the THC, all sediment samples were discarded. This discard was in conformance with THC guidelines. Upon completion of the project, all remaining materials and records will be permanently curated at the CAR facility. 



\section{Chapter 4: Survey Results}

The survey of the Kendall County Park project area was completed in February 2010. This chapter discusses the results of the pedestrian survey. The fieldwork consisted of a linear intensive pedestrian survey accompanied by shovel testing $(n=22)$ of the existing park road that is targeted for improvement, an intensive pedestrian survey accompanied by shovel testing $(n=42)$ of the 117 acre project area, a 100 percent pedestrian reconnaissance, mechanically excavated backhoe trenches to investigate any deposits that could not be effectively explored using shovel testing $(n=2)$, and profile documentation of an existing cutbank.

The pedestrian survey, shovel testing, and backhoe trenching of the project area revealed no evidence of historic artifacts and no instances of subsurface prehistoric cultural material. One scatter of surface artifacts was documented and designated as archaeological site 41KE214. Isolated finds, consisting of debitage $(n=13)$, tools $(\mathrm{n}=2)$, one core, and burned rock $(\mathrm{n}=2)$, and an isolated instance of two mortar holes, were noted on the project area.

\section{Shovel Tests}

Sixty-four shovel tests were excavated during the survey of the Kendall County Park project. Fourteen of the sixty-four shovel tests $(21 \%)$ were excavated to $60 \mathrm{cmbs}$ (Figure 4-1). Eleven of these fourteen (79\%) were located on

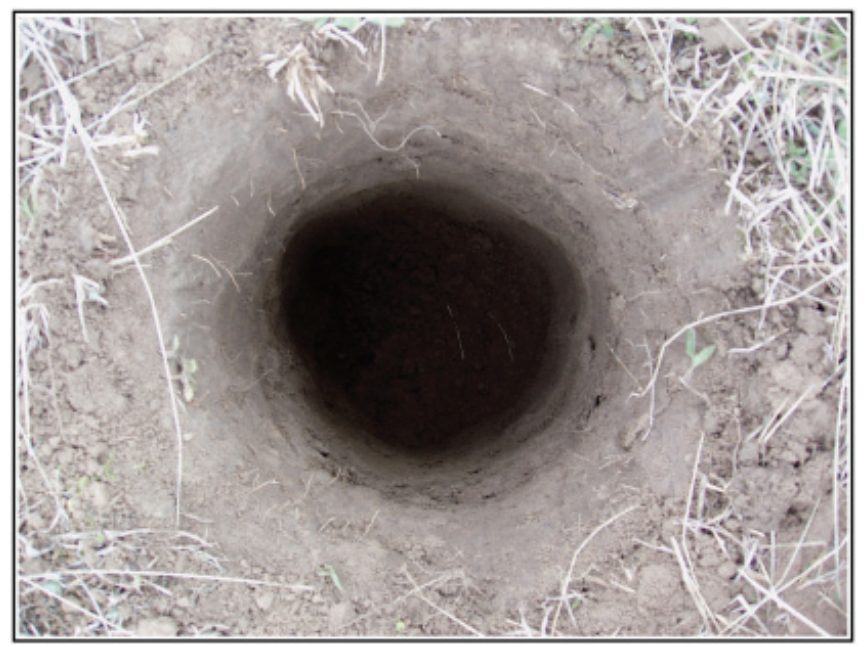

Figure 4-1. Termination of Shovel Test 47 at $60 \mathrm{cmbs}$.

the northern portion of the project area off the karst formations. The remaining 50 shovel tests were terminated at depths ranging from 5 to $53 \mathrm{cmbs}$ due to large roots ( $2 \%)$, bedrock ( $75 \%$; Figure $4-2)$, or commencement of the water table (2\%; Table 4-1; Figure 4-3). Shovel Test 38 was abandoned before reaching $60 \mathrm{cmbs}$ due to a shallow water table. This test was located in a low area near an inundated bog. None of the shovel tests were positive.

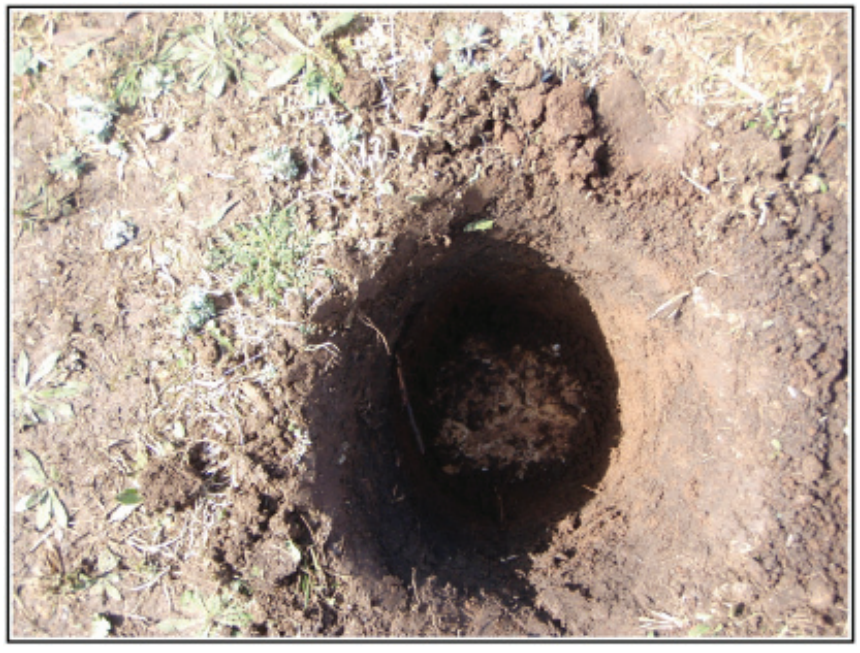

Figure 4-2. Termination of Shovel Test 9 at 29 cmbs upon exposing bedrock.

The soils from the sixty-four shovel tests corresponded for the most part to the soil type as located and describe by Dittemore and Hensell (1981) and Soil Survey Staff (2010; Figure 4-4). In general, the tests excavated on the terrace near the Guadalupe River consisted of a grayish brown silty sand in Level 1 changing to a dark gray to yellowish red silty sand by Level 5 . However, note that near the far southern edge of the terrace the soil color in Level 1 changes to a dark gray to yellowish red silty sand (see Figure 4-4). The terrace is cut by a ravine and is composed of two soil types, Boerne fine sandy loam east of the ravine and Ekrant-Comfort association west of the ravine. The color pattern revealed by the CAR's shovel testing suggests that the Boerne fine sandy loam on the eastern side of the terrace continues onto the terrace located on the western side of the ravine where the soil survey (Dittemore and Hensell 1981; Soil Survey Staff 2010) documents Ekrant-Comfort association. However, the shovel tests on the western side of the ravine tended to contain roots and low levels of pebbles, whereas the shovel tests on the eastern side were free of inclusions. The eastern side appears to have been cleared and there is evidence of a surface burn. The western side is consistently covered with large trees (see Figure 2-5). 
Table 4-1. Termination Depths of Shovel Tests

\begin{tabular}{|c|c|c|c|c|c|c|c|}
\hline $\begin{array}{c}\text { Shovel } \\
\text { Test }\end{array}$ & $\begin{array}{c}\text { Termination } \\
\text { Level }\end{array}$ & $\begin{array}{l}\text { Depth } \\
\text { (cmbs) }\end{array}$ & $\begin{array}{l}\text { Reason for } \\
\text { Termination }\end{array}$ & $\begin{array}{c}\text { Shovel } \\
\text { Test }\end{array}$ & $\begin{array}{c}\text { Termination } \\
\text { Level }\end{array}$ & $\begin{array}{l}\text { Depth } \\
\text { (cmbs) }\end{array}$ & $\begin{array}{l}\text { Reason for } \\
\text { Termination }\end{array}$ \\
\hline 1 & 3 & 22 & bedrock & 28 & 6 & 60 & complete \\
\hline 2 & 3 & 23 & bedrock & 29 & 1 & 9 & bedrock \\
\hline 3 & 3 & 30 & bedrock & 30 & 3 & 28 & bedrock \\
\hline 4 & 2 & 11 & bedrock & 31 & 5 & 50 & bedrock \\
\hline 5 & 3 & 26 & bedrock & 32 & 3 & 30 & bedrock \\
\hline 6 & 4 & 31 & bedrock & 33 & 4 & 38 & bedrock \\
\hline 7 & 3 & 30 & bedrock & 34 & 2 & 20 & bedrock \\
\hline 8 & 6 & 60 & complete & 35 & 3 & 30 & bedrock \\
\hline 9 & 3 & 29 & bedrock & 36 & 3 & 30 & bedrock \\
\hline 10 & 3 & 26 & bedrock & 37 & 3 & 22 & bedrock \\
\hline $10 a$ & 2 & 20 & bedrock & 38 & 3 & 30 & water table \\
\hline $10 \mathrm{~b}$ & 2 & 14 & bedrock & 39 & 6 & 60 & complete \\
\hline $10 c$ & 3 & 28 & bedrock & 40 & 2 & 17 & bedrock \\
\hline $10 \mathrm{~d}$ & 3 & 25 & bedrock & 41 & 1 & 8 & bedrock \\
\hline $10 \mathrm{e}$ & 6 & 53 & bedrock & 42 & 6 & 60 & complete \\
\hline 11 & 6 & 60 & complete & 43 & 6 & 60 & complete \\
\hline 12 & 6 & 60 & complete & 44 & 3 & 25 & bedrock \\
\hline 13 & 5 & 42 & bedrock & 45 & 4 & 32 & bedrock \\
\hline 14 & 3 & 27 & bedrock & 46 & 6 & 60 & complete \\
\hline 15 & 6 & 52 & bedrock & 47 & 6 & 60 & complete \\
\hline 16 & 1 & 10 & bedrock & 48 & 6 & 60 & complete \\
\hline 17 & 2 & 17 & bedrock & 49 & 6 & 60 & complete \\
\hline 18 & 1 & 10 & bedrock & 50 & 6 & 60 & complete \\
\hline 19 & 4 & 40 & bedrock & 51 & 2 & 14 & bedrock \\
\hline 20 & 1 & 9 & bedrock & 52 & 4 & 31 & bedrock \\
\hline 21 & 1 & 9 & bedrock & 53 & 2 & 20 & bedrock \\
\hline 22 & 3 & 27 & bedrock & 54 & 6 & 60 & complete \\
\hline 23 & 1 & 9 & bedrock & 55 & 4 & 35 & large root \\
\hline 24 & 2 & 18 & bedrock & 56 & 6 & 60 & complete \\
\hline 25 & 2 & 20 & bedrock & 57 & 5 & 50 & bedrock \\
\hline 26 & 3 & 22 & bedrock & 58 & 3 & 25 & bedrock \\
\hline 27 & 2 & 18 & bedrock & 59 & 1 & 5 & bedrock \\
\hline
\end{tabular}

The Ekrant-Comfort association (see Figure 4-4) continues south of the terrace on the western side and is located south of the Boerne fine sandy loam on the eastern side of the property. The soil color on this association ranges from black to brown (black, very dark gray, very dark brown, dark reddish brown, very dark grayish brown, dark brown, and brown). Although three shovel tests were excavated through Level 6 (50$60 \mathrm{cmbs}$ ), shovel tests on this soil type, on average, were terminated in Level $3(20-30 \mathrm{cmbs})$ due to shallow exposures of bedrock. For the most part, soils contained roots and pebbles and were composed of silty clay near the surface becoming higher in clay content in the deeper levels.

Eleven shovel tests were located on the two remaining soil types on the project area, Krum silty clay $(n=4)$ and Ekrant-Rock outcrop association ( $n=7$; see Figure 4-4). 
The four tests on the Krum silty clay ranged in color from browns to grays (very dark brown, grayish brown, and very dark gray) with two of the four tests changing to brown and dark reddish brown sediment at Level 5. Two of the shovel tests reached Level 2 and two continued to Level 6. The major drainage to the Guadalupe River on the property runs through this soil type and a large portion, near the two northern shovel tests, was underwater. The

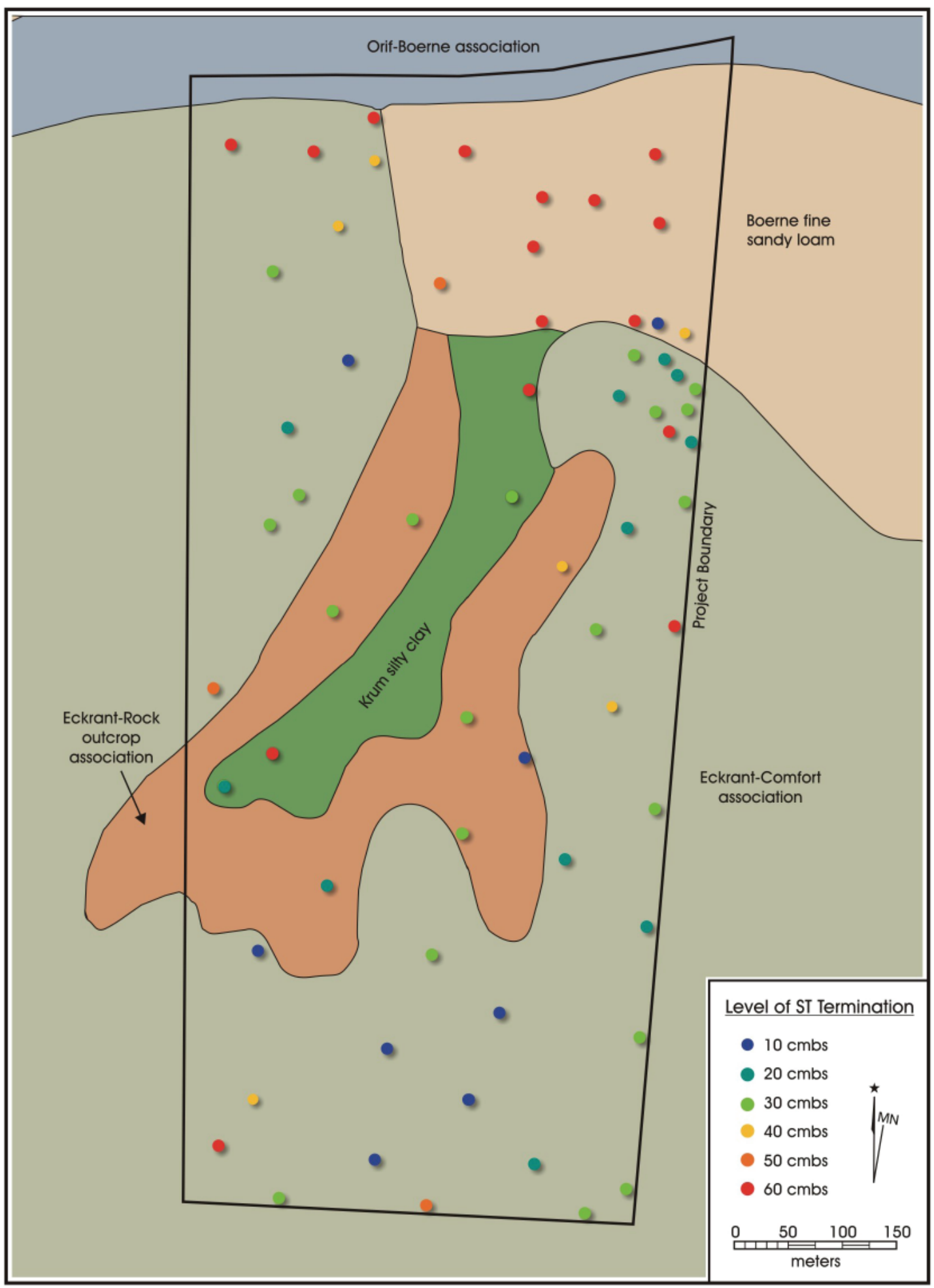

Figure 4-3. Soil map of project area showing termination depths of shovel tests. 


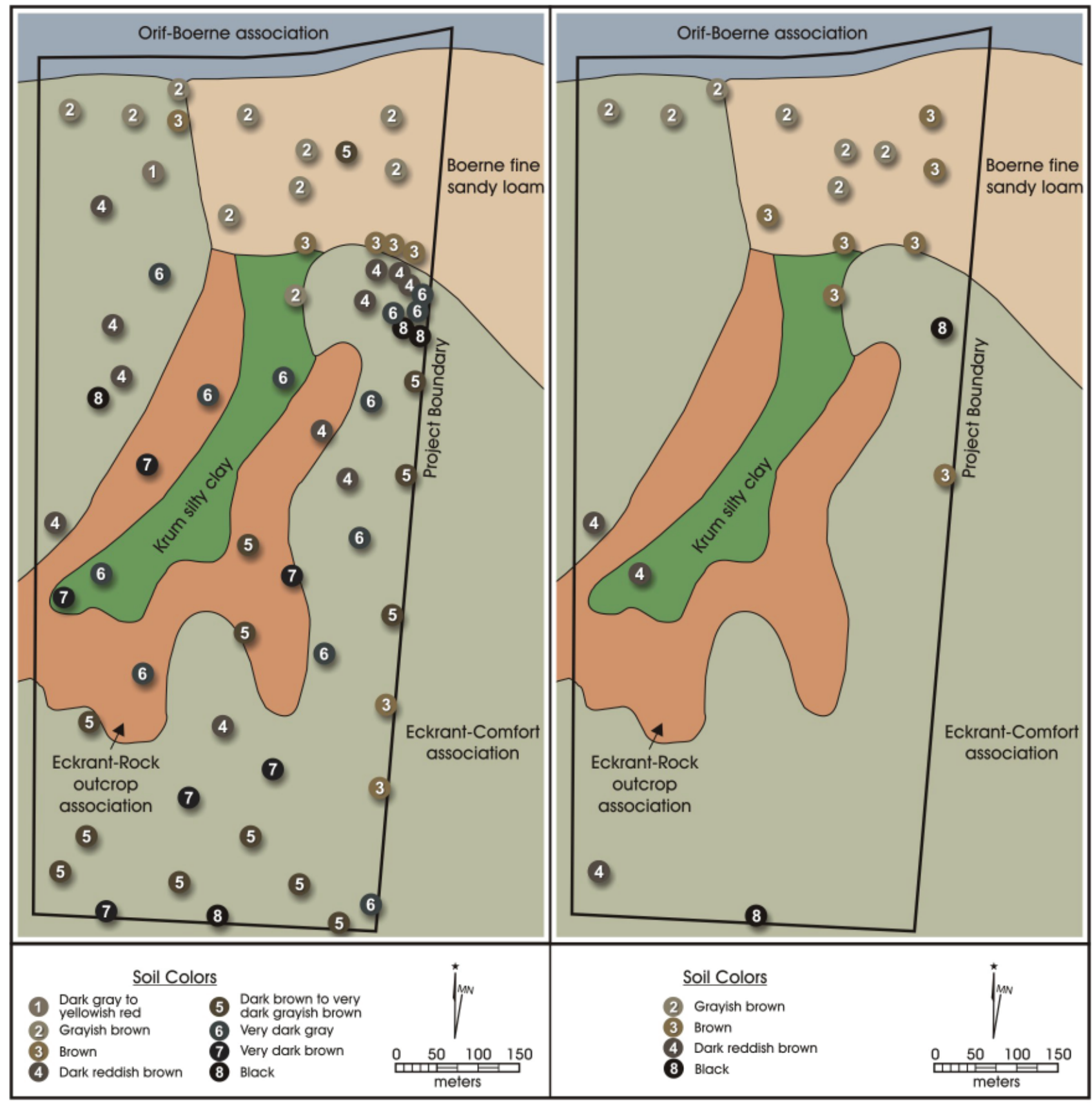

Figure 4-4. Soil colors from Level 1 (left) and Level 5 (right) of the shovel tests on a soil map of the project area.

soils contained roots and pebbles near the surface and consisted of silty clays. All the shovel tests located on the Ekrant-Rock outcrop association (very dark gray, very dark brown, and dark brown to very dark grayish brown) reached termination before Level 5 with an average termination in Level 3. This association contains large outcroppings of exposed bedrock.

\section{Backhoe Trenching}

To address the high potential for deeply buried intact paleosols and cultural material in the terrace adjacent to the Guadalupe River, two backhoe trenches were mechanically excavated and a large existing cutbank near the river was profiled. The backhoe trenches were 
positioned along the eastern terrace. Because the terrace on the western side of the ravine was inaccessible to the backhoe due to a large bog covering the area of access, three additional shovel tests (STs 54, 55, and 56) were excavated in lieu of the excavation of a third trench. The soils in the three tests were comparable to the soils in the shovel tests on the eastern side of the ravine.

Backhoe Trench (BHT) 1 was excavated on the west side of the eastern portion of the terrace and BHT 2 was placed on the east side. Backhoe Trench 1 consisted of a grayish brown sandy sediment (10YR5/2) with specs of charcoal from 0 to $19 \mathrm{cmbs}$ (Figure 4-5). A brown sandy deposit (10YR5/3) was evident from $19 \mathrm{cmbs}$ to the base of the trench $(150 \mathrm{cmbs})$. Backhoe Trench 2 was similar to BHT 1 with grayish brown sandy material with charcoal specs from 0 to $8 \mathrm{cmbs}$ and brown sandy soil from 10 to 150 cmbs. Unlike BHT 1, BHT 2 contained a layer of charcoal, associated with a modern burn event, from approximately 8 to $10 \mathrm{cmbs}$ (Figure 4-6). No features or artifacts were identified in the walls of either BHT 1 or 2 . The walls in both trenches, other than a couple of snails, were devoid of any inclusions. No cultural material was observed in the backdirt associated with the trenches.

A large, deep cutbank, located on the edge of the terrace adjacent to the river, was cut back and profiled to further document the stratigraphy of the terrace (Figure 4-7). Two obvious breaks in color dividing the profile into three soil units were documented. The material from 0 to 60 cmbs consists of a clayey sand with roots from surface vegetation and grades from black (5YR2.5/1) on the surface to very dark brown (10YR2.5/2) to a dark reddish brown $(5 Y R 3 / 3,5 Y R 3 / 4$, and 5YR2.5/2). The second unit was from 60 to $200 \mathrm{cmbs}$ and contains a sandy deposit with few roots. The material grades from a dark reddish brown (5YR3/3, 5YR3/4, and 5YR2.5/2) to a dark gray to yellowish red (5YR4/1 and 5YR5/6) to brown (10YR4/3). The lower levels of the cutbank consist of a harder, more compact sand with inclusions of snails at low densities. The color changes abruptly from the previous unit to a redder shade of brown (7.5YR5/4 and 7.5YR4.4). The colors and textures noted in the backhoe trenches are similar to the middle unit (60-200 cmbs). All three divisions found in

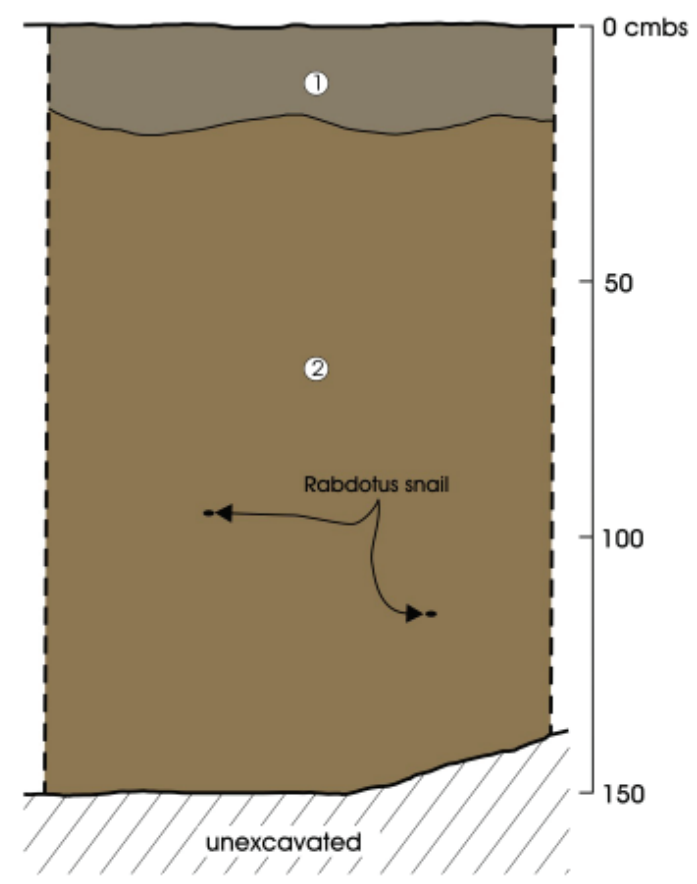

(1) Grayish brown (10YR5/2) sandy sediment (2) Brown (10YR5/3) sandy sediment

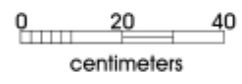

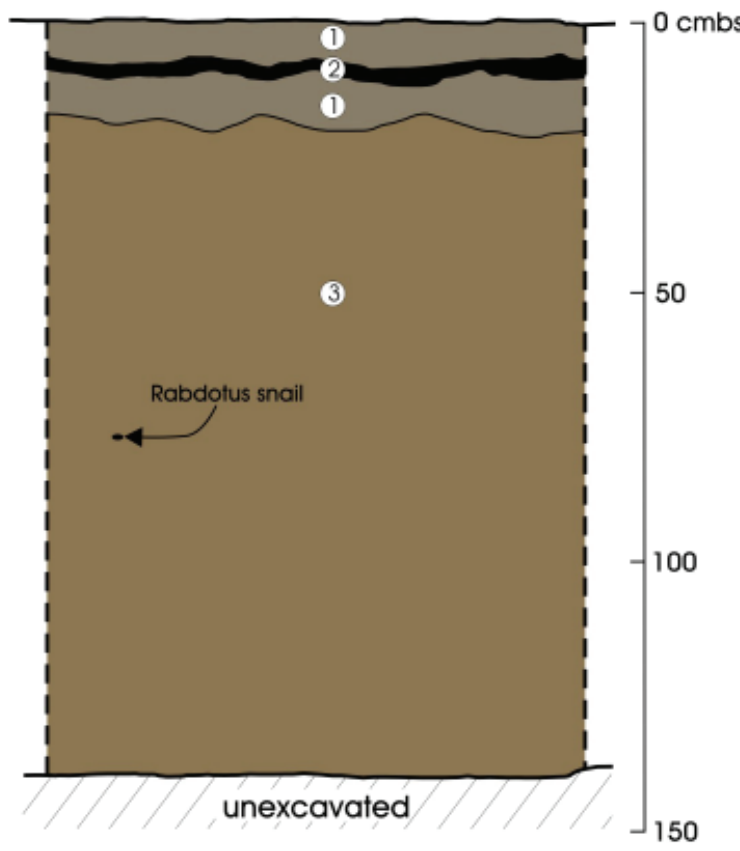

1) Grayish brown (10YR5/2) sandy sediment

2. Layer of modern charcoal

(3) Brown (10YR5/3) sandy sediment

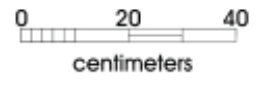




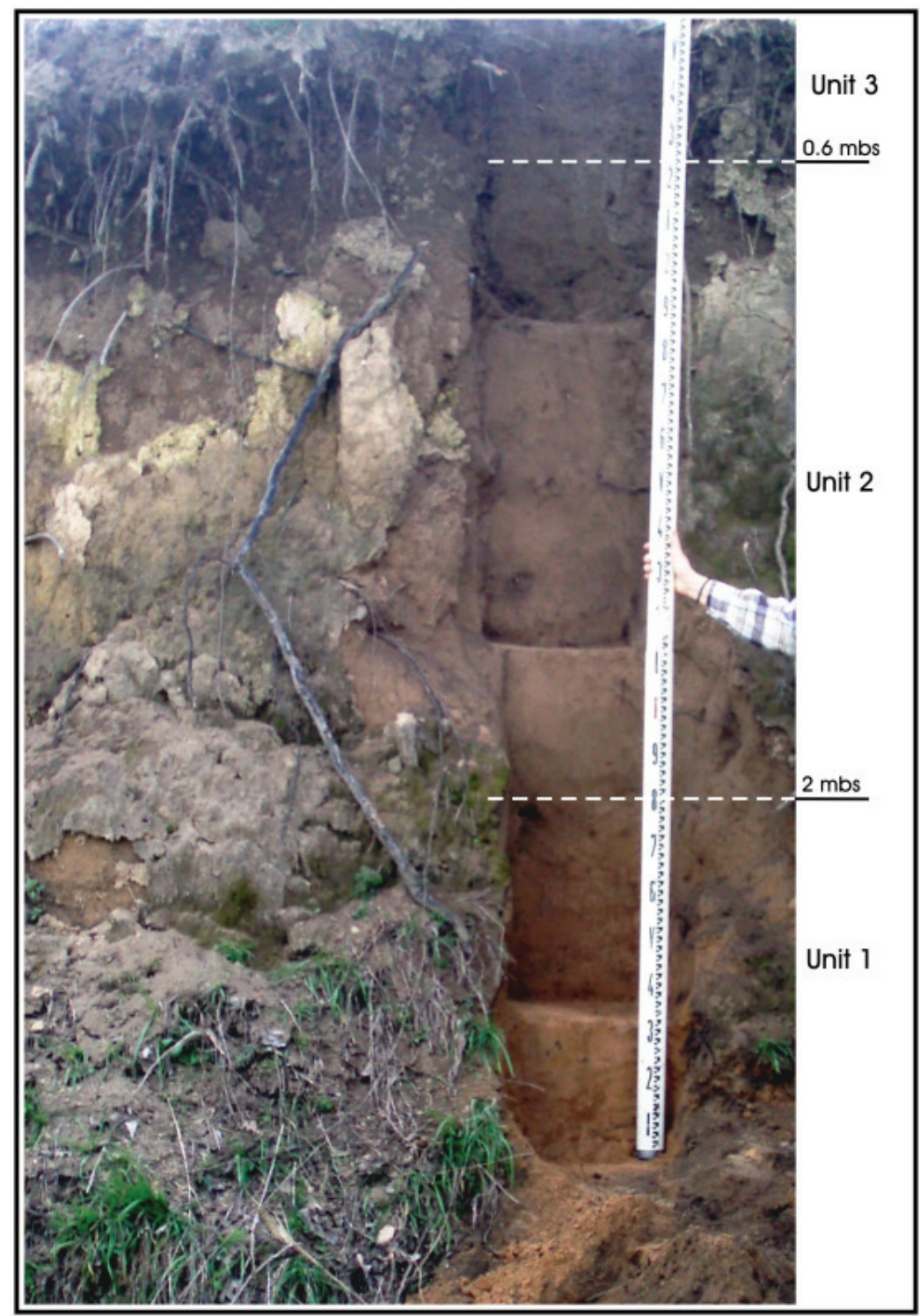

Figure 4-7. Cutbank on the project area along the south bank of the Guadalupe River.

the cutbank are free of the mottling or gravel deposits commonly associated with high-energy flood events.

\section{Reconnaissance of the Project Area}

In addition to the shovel testing and trenching, the survey consisted of a 100 percent pedestrian reconnaissance of the 117 acre project area. The CAR field crew traversed the project area along transects evenly spaced at 30 meters. During the reconnaissance, 18 surface artifacts (13 specimens of lithic debitage, 2 tools, 1 core, and 2 pieces of burned rock) were recorded as isolated finds at 13 isolated spots on the property (Figure 4-8). These artifacts were not found in concentrations meeting the CAR's definition of an archaeological site (i.e., five or more surface artifacts within a 15-meter radius). A lithic scatter qualifying as a site was also documented and is discussed in the following section. Of interest, all but two isolated finds were documented in areas fairly clear of vegetation (i.e., roads, clearings, under power lines) suggesting that surface artifacts may be more widespread on the property but are currently obscured by vegetation and leaf clutter.

One large boulder containing two mortar holes was noted adjacent to the north-south fence line bisecting the property on the southern third of the project area (Figure 4-9). The boulder is located in an area of exposed bedrock. The area within a $30-\mathrm{m}$ radius of the mortar holes was canvassed to ascertain if any other holes or artifacts were evident 
in the immediate area. Because other evidence of cultural material could not be found, the mortar holes were treated as an isolated find. The mortar holes measured 23 and 22 $\mathrm{cm}$ deep with diameters of $16 \mathrm{~cm}$ and $12 \mathrm{~cm}$, respectively. The holes are $16 \mathrm{~cm}$ apart. They both had fairly straight walls except for the walls nearest to one another (Figure 4-10). These walls sloped toward each other perhaps as a result of erosion from years of natural water collection. The mortar holes are reminiscent of others documented in central Texas (Mauldin et al. 2003; Riemenschneider and Turpin 1998).
During the reconnaissance of the project area the field crew noted several geologic features common to areas of karst formations; specifically, two sinkholes, a seep, and a cave (Figure 4-11). Karst regions, formed by the dissolution of soluble rocks, including limestone and dolomite, typically are landscapes made up of caves and sinkholes containing large aquifers, such as the Edwards Aquifer. These caves and sinkholes are often sites of prehistoric interments although they are not often associated with occupations (Potter et al. 2005). These burial sites tend to be inaccessible and confined (Hester et

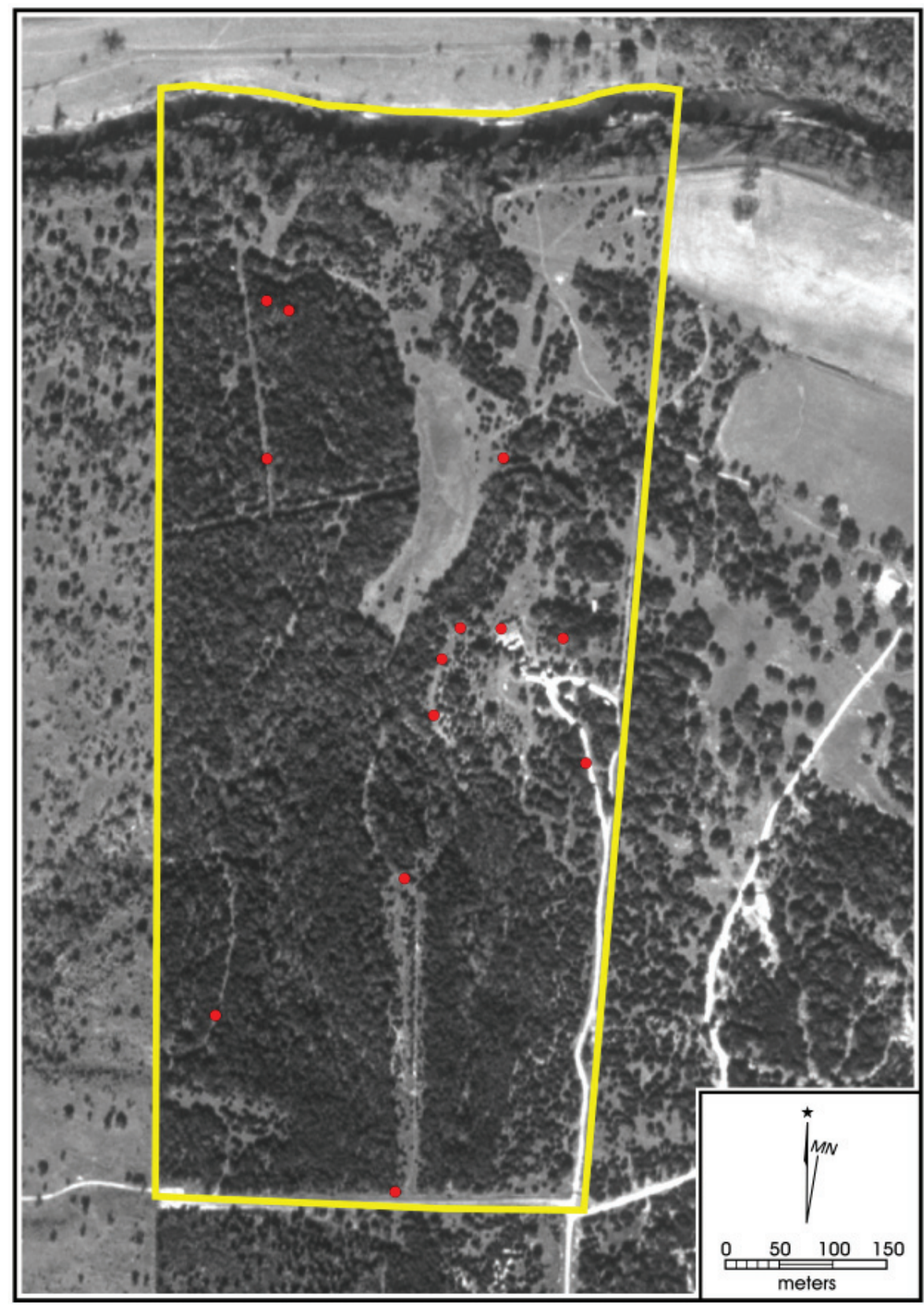

Figure 4-8. Location of isolated finds (lithic artifacts) on the project area. 


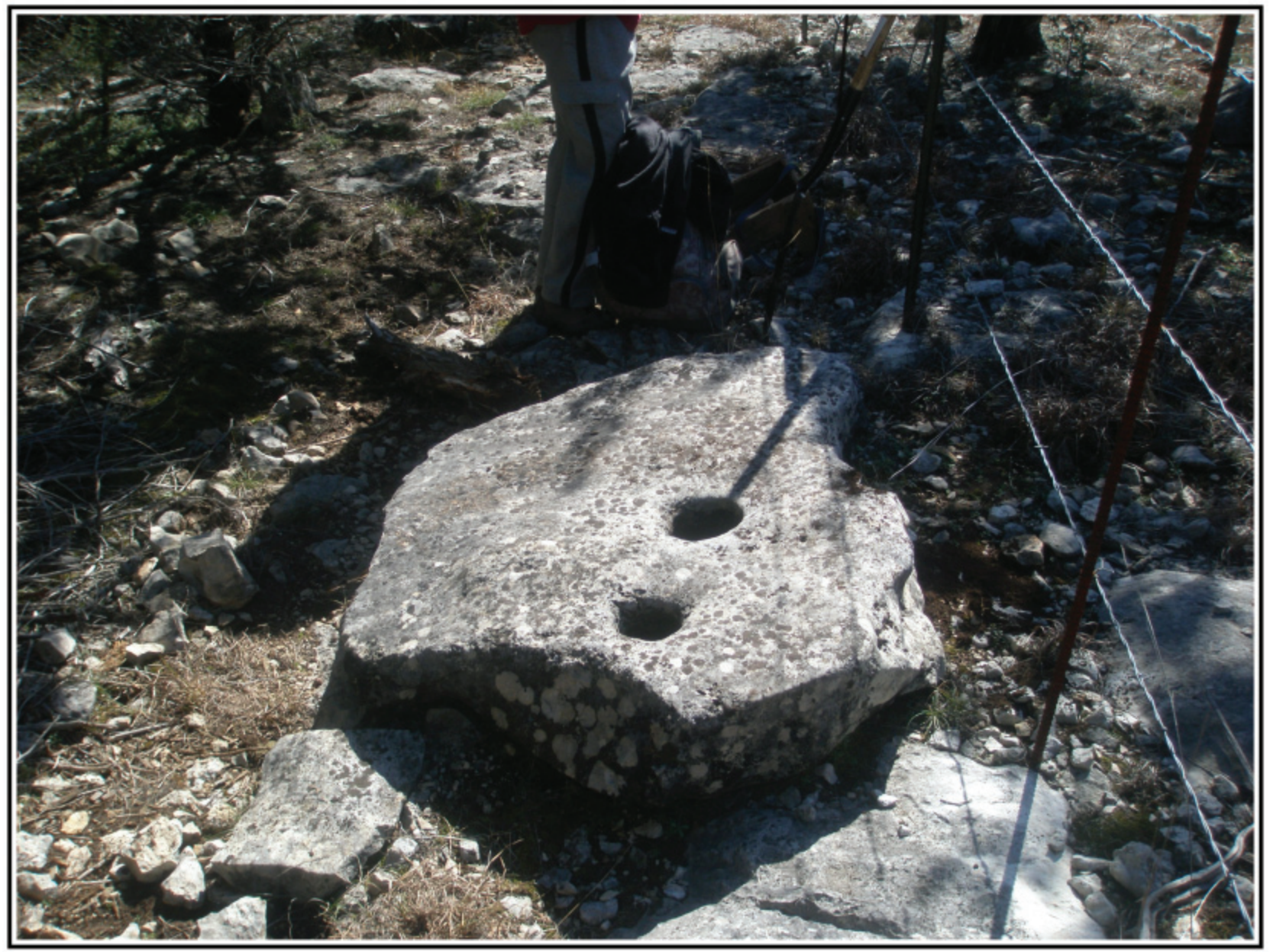

Figure 4-9. Boulder containing two mortar holes.

al. 1998), and are often vertical shafts where burials were dropped through an opening into the shaft (Turpin and Bement 1988). Sinkhole burials do not usually occur in association with archaeological deposits, whereas, cave and rockshelter interments are often found in conjunction with cultural debris indicating site occupation and use (Perttula 2001). Large numbers of burials have been found in karst settings, such as Bering Sinkhole in Kerr County (Bement 1991, 1994), Seminole Sink in Val Verde County (Turpin 1988; Turpin and Bement 1988) and Hitzfelter Cave in Bexar County (Givins 1968; Scruggs et al. 1978). Isolated single burials occur throughout Central and South Texas, notably in karst settings on the southern edge of the Edward's Plateau in Bexar County.

The sinkholes noted on the project area both have large openings. One is approximately $1-\mathrm{x}-1 \mathrm{~m}$ with a decreasing width to $60 \mathrm{~cm}$ in the midsection (Figure 4-12). This sinkhole, measured by dropping a tape weighted with a flashlight, is at least $7.5 \mathrm{~m}$ deep with walls that drop vertically from the surface. The opening of the second sinkhole is approximately $40 \mathrm{~cm}$ in diameter. The depth of the sinkhole was not measured but is visually estimated at three to six meters. A cave entrance, noted during the reconnaissance, is located at the highpoint of a portion of the main property drainage (Figure 4-13). The cave and drainage area is currently dry but during heavy rains, water must flow down over the rocks above the cave, creating a waterfall in front of the cave, and continue down the drainage to the Guadalupe River. Because safety concerns prohibited subsurface investigation of the cave and sinkholes, it is not known if the features contain interments or other cultural materials. However, due to the preponderance of cave and sinkhole burials on the Edwards Plateau, there is a moderate likelihood for prehistoric human use. Therefore, the cave and sinkhole openings should be protected to prevent exploration and looting of potential cultural material until these locations can be assessed for significance. The sinkholes also are a safety concern. 


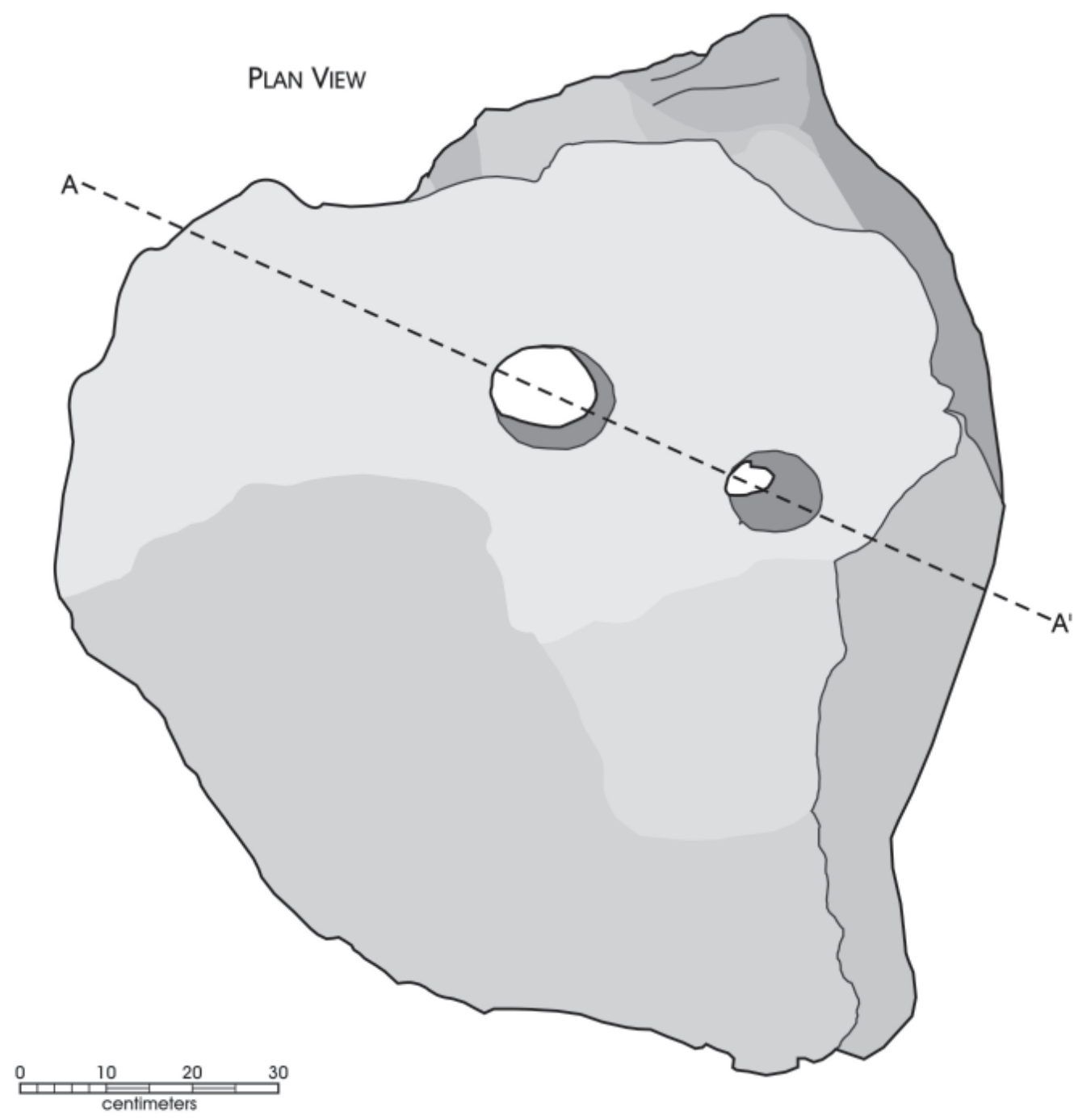

ESTIMATED PROFILE (based on measurements)

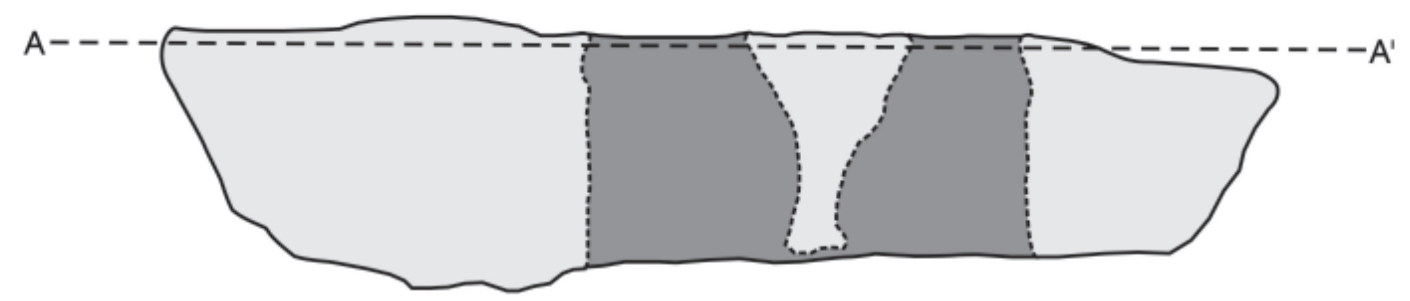

Figure 4-10. Sketch of mortar holes showing dimensions, based on measurements in the field. 


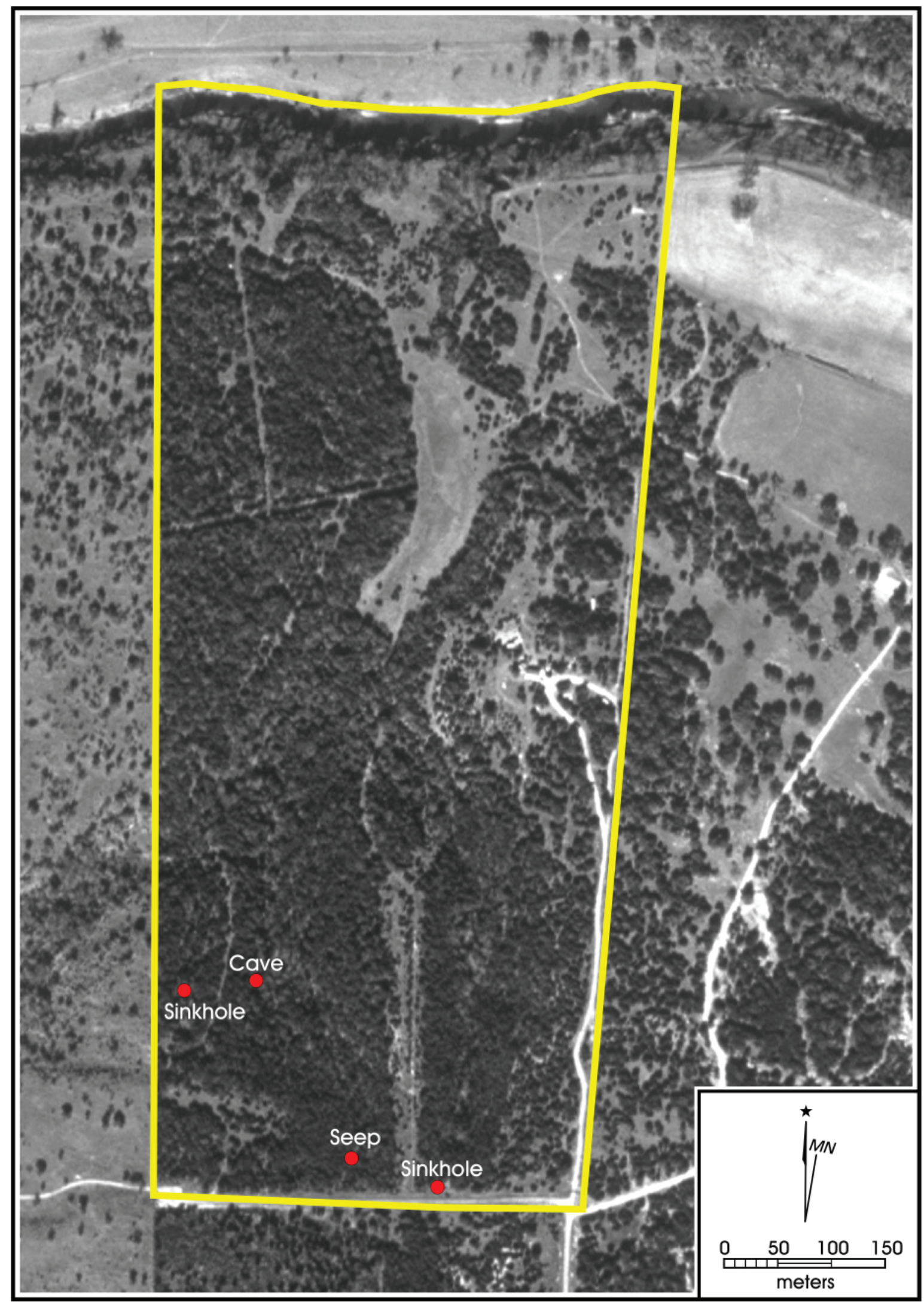

Figure 4-11. Aerial map of project area noting location of two sinkholes, one seep, and a cave. 


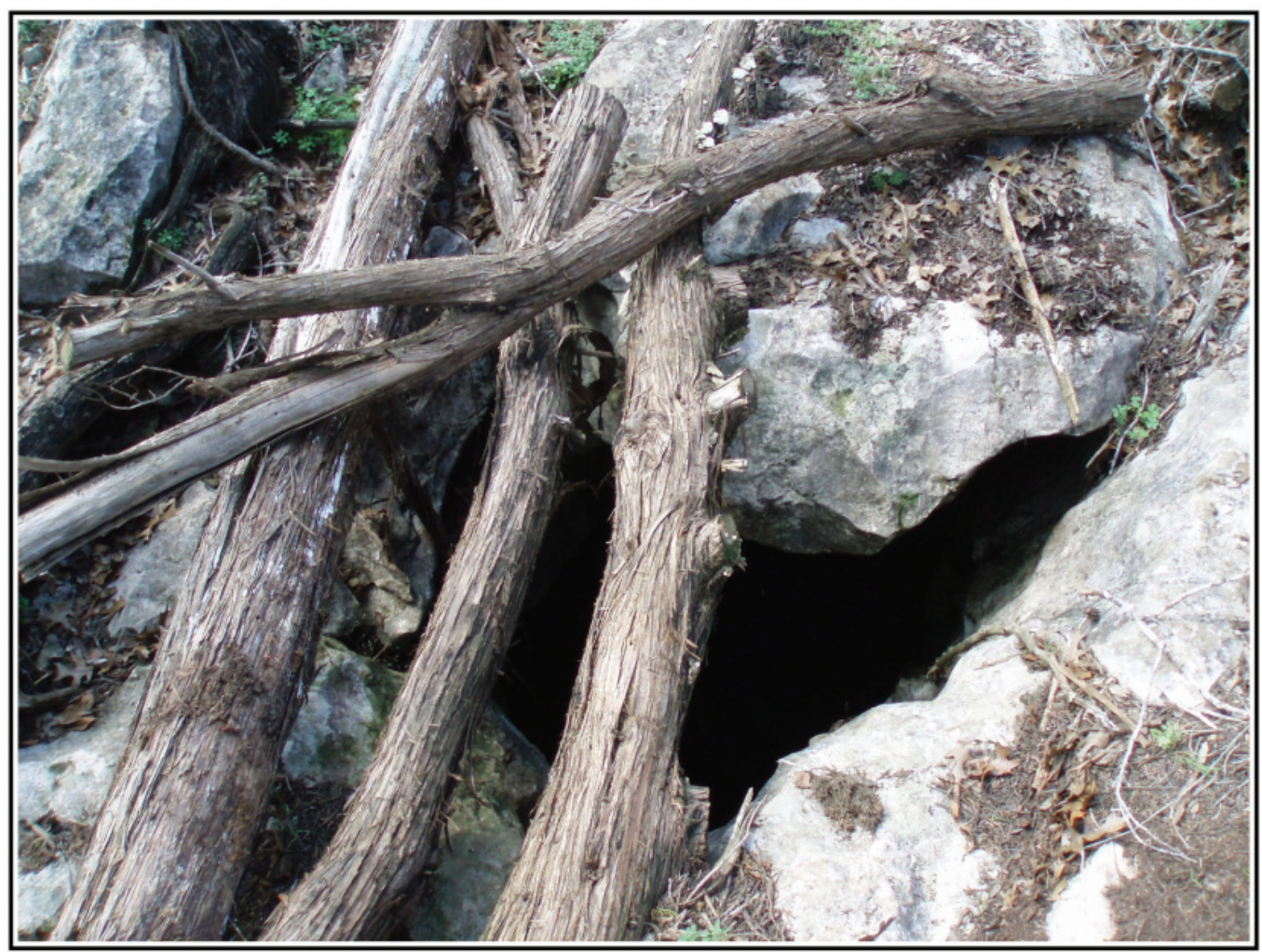

Figure 4-12. Sinkhole located near southern boundary of the project area (note that dimensions are 1 $m$ by $1 \mathrm{~m}$ decreasing to $60 \mathrm{~cm}$ in midsection).

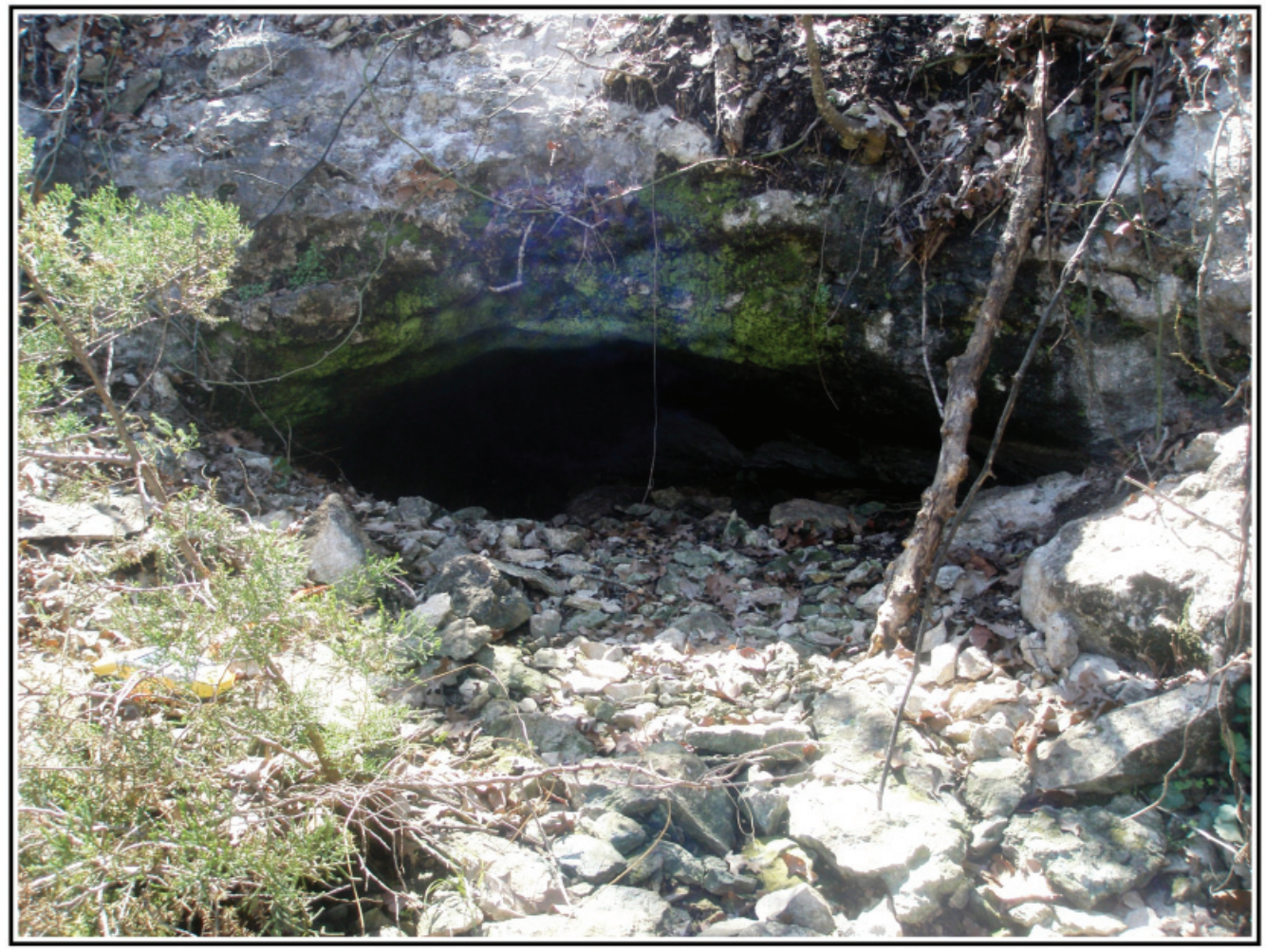

Figure 4-13. Cave located on southern portion of project area. 


\section{Archaeological Site 41KE214}

In the process of conducting the Kendall County Park survey, one new archaeological site was identified, $41 \mathrm{KE} 214$ (Figure 4-14). The site, consisting of a surface scatter of lithic debitage $(n=40+)$, tools $(n=3)$, and a small area of burned rock $(n=4)$ not associated with charcoal or staining (Figures 4-15, 4-16 and 4-17), is located directly on the park road, adjacent to the eastern property boundary, approximately $274 \mathrm{~m}$ south of the Guadalupe River. The artifact scatter is spread over approximately $118 \mathrm{~m}$ of the park road. Ten shovel tests, two located in the scatter and eight on the edges of the scatter, were excavated to determine the depth of the site and to delineate the site's boundary. All shovel tests were negative. One additional shovel test, excavated previously during the survey of the park road, was also negative. The road section containing the southern extent of the scatter is bounded by a fairly heavy brush and tree canopy and is heavily disturbed from feral hog activity (Figure 4-18). The road section containing the northern extent however, is bounded by cleared land on which evidence of the lithic scatter continues off the road (Figure 4-19). Based on the visible edges of the scatter, the site covers $4,450 \mathrm{~m}^{2}$. No diagnostic artifacts or features were noted. Because of the lack of material depth, features, and diagnostics, the potential for future research value is low.

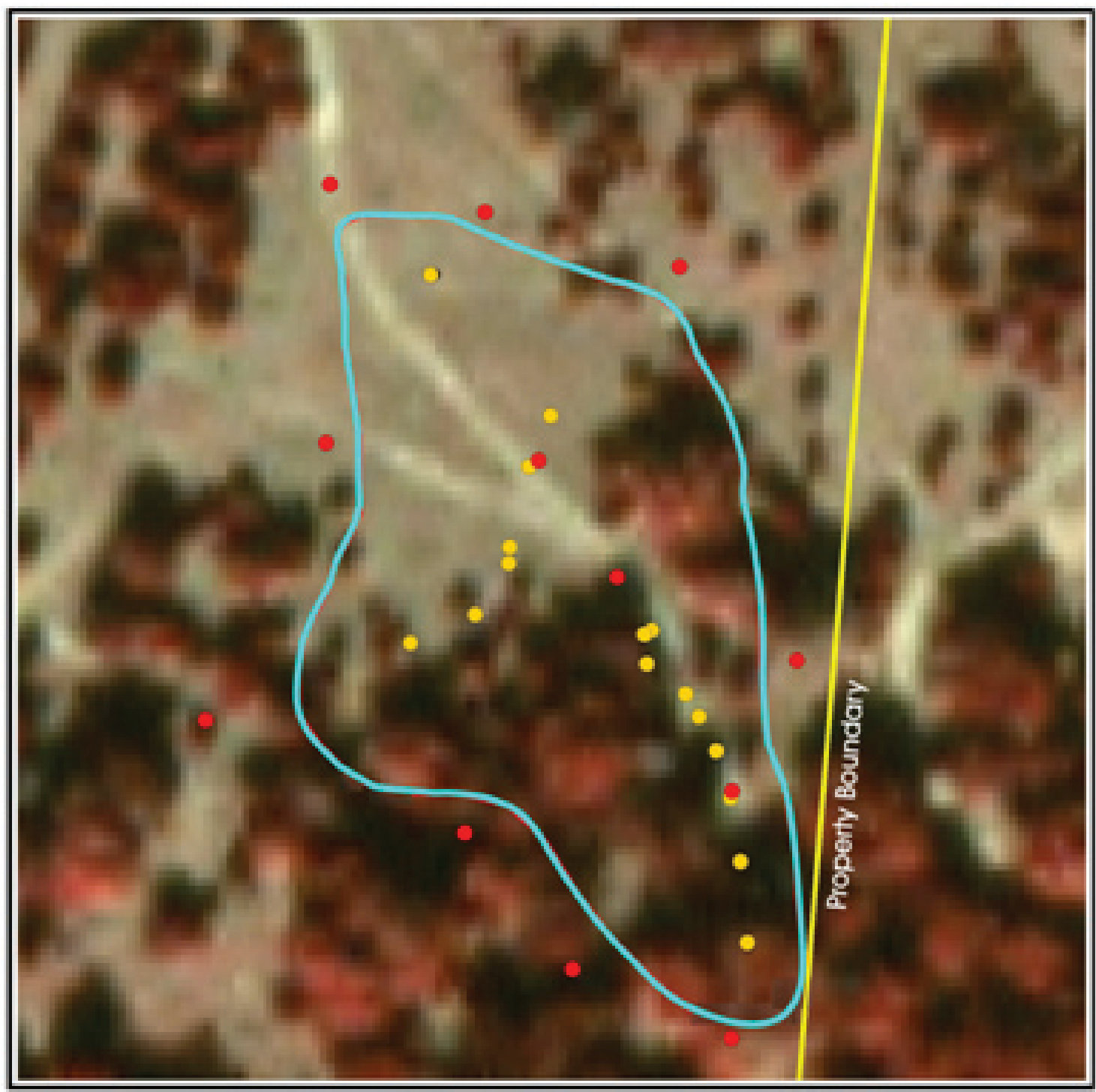

Figure 4-14. Aerial map of 41KE214 showing site boundary (blue), location of shovel tests (red), and location of surface artifacts (yellow). 


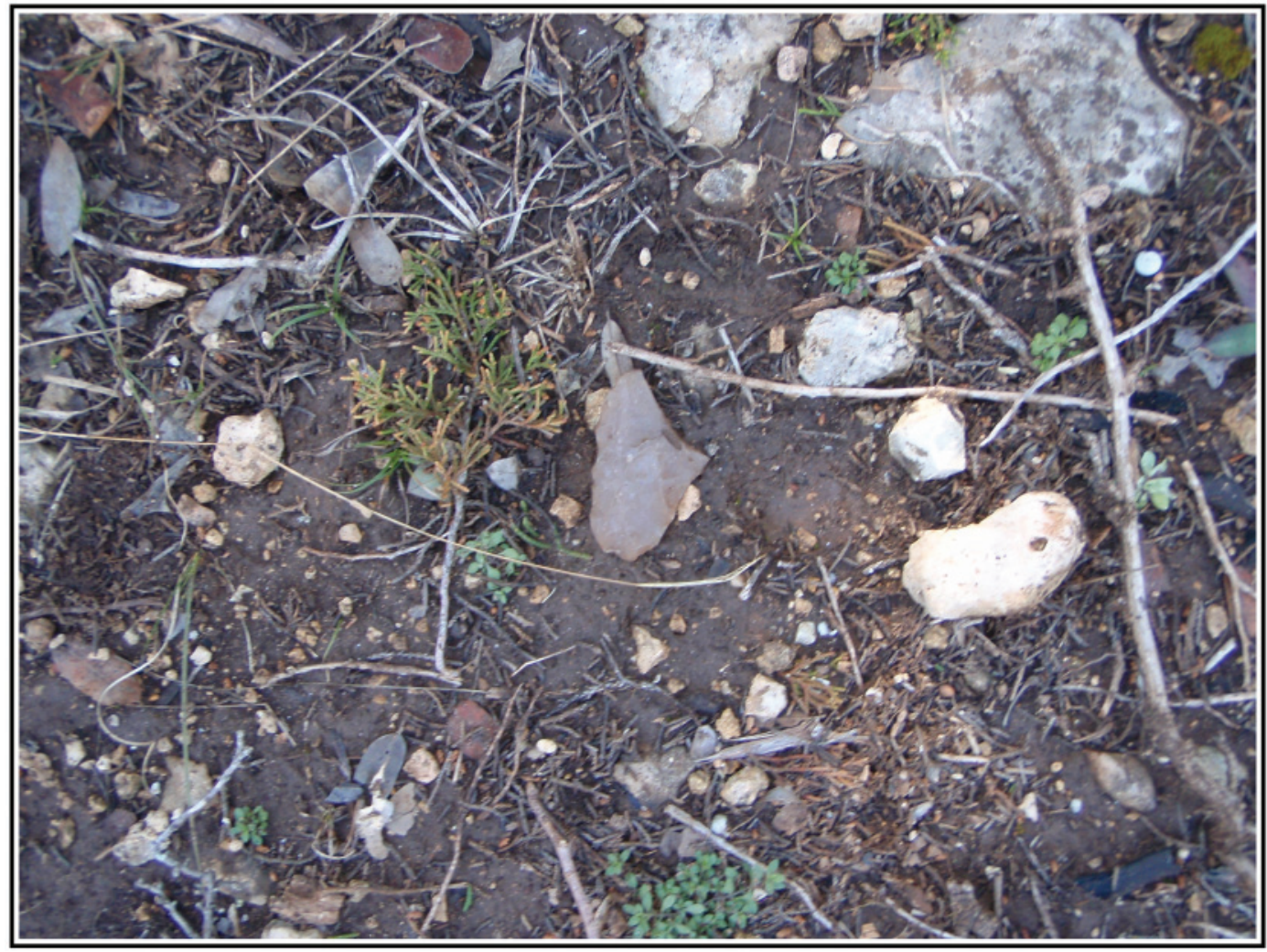

Figure 4-15. Biface located adjacent to the park road on site 41KE214.

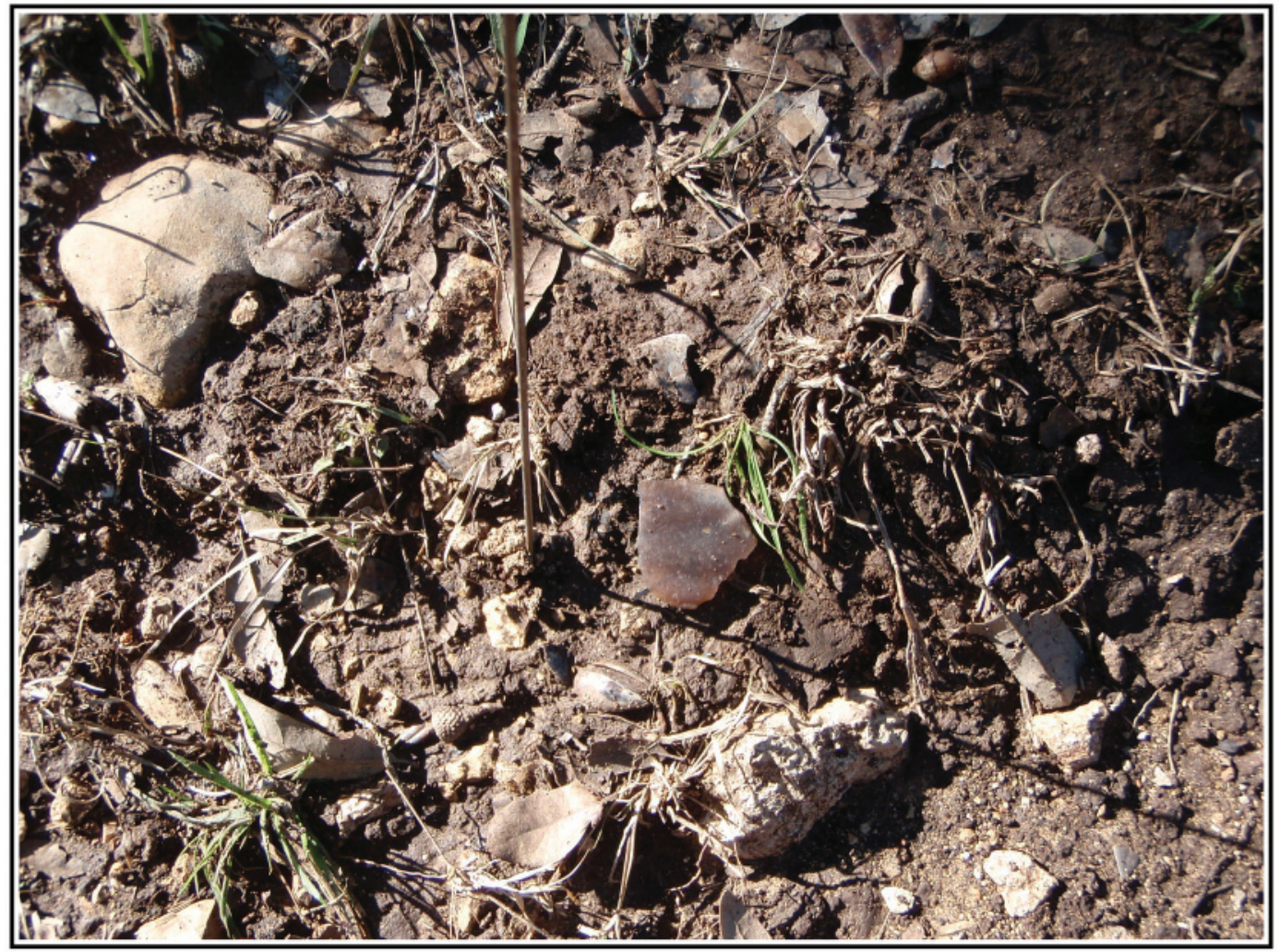

Figure 4-16. Debitage specimen located on the park road on site 41KE214. 


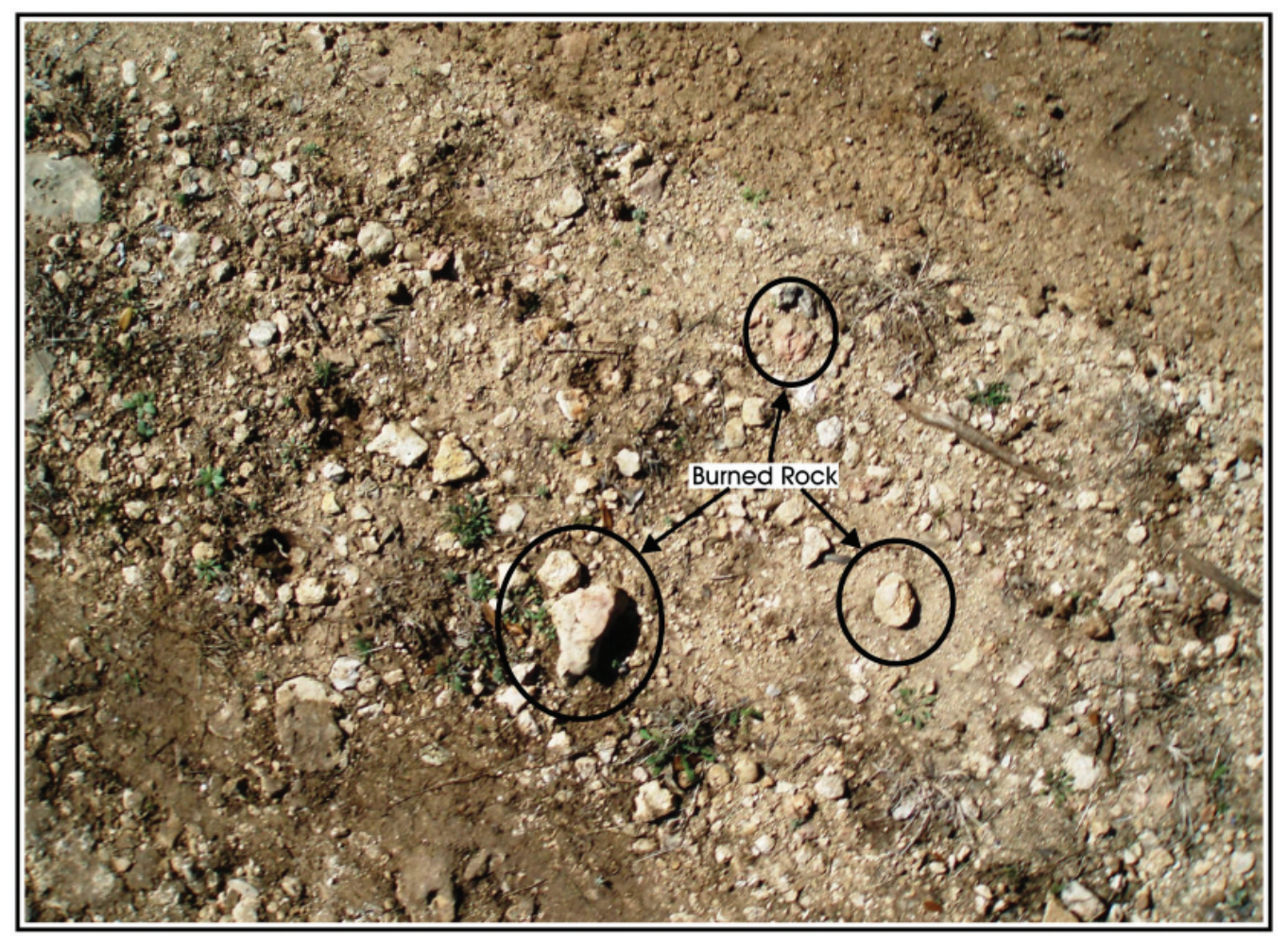

Figure 4-17. Burned rock without any staining or charcoal located in the center of the existing park road on site $41 K E 214$.

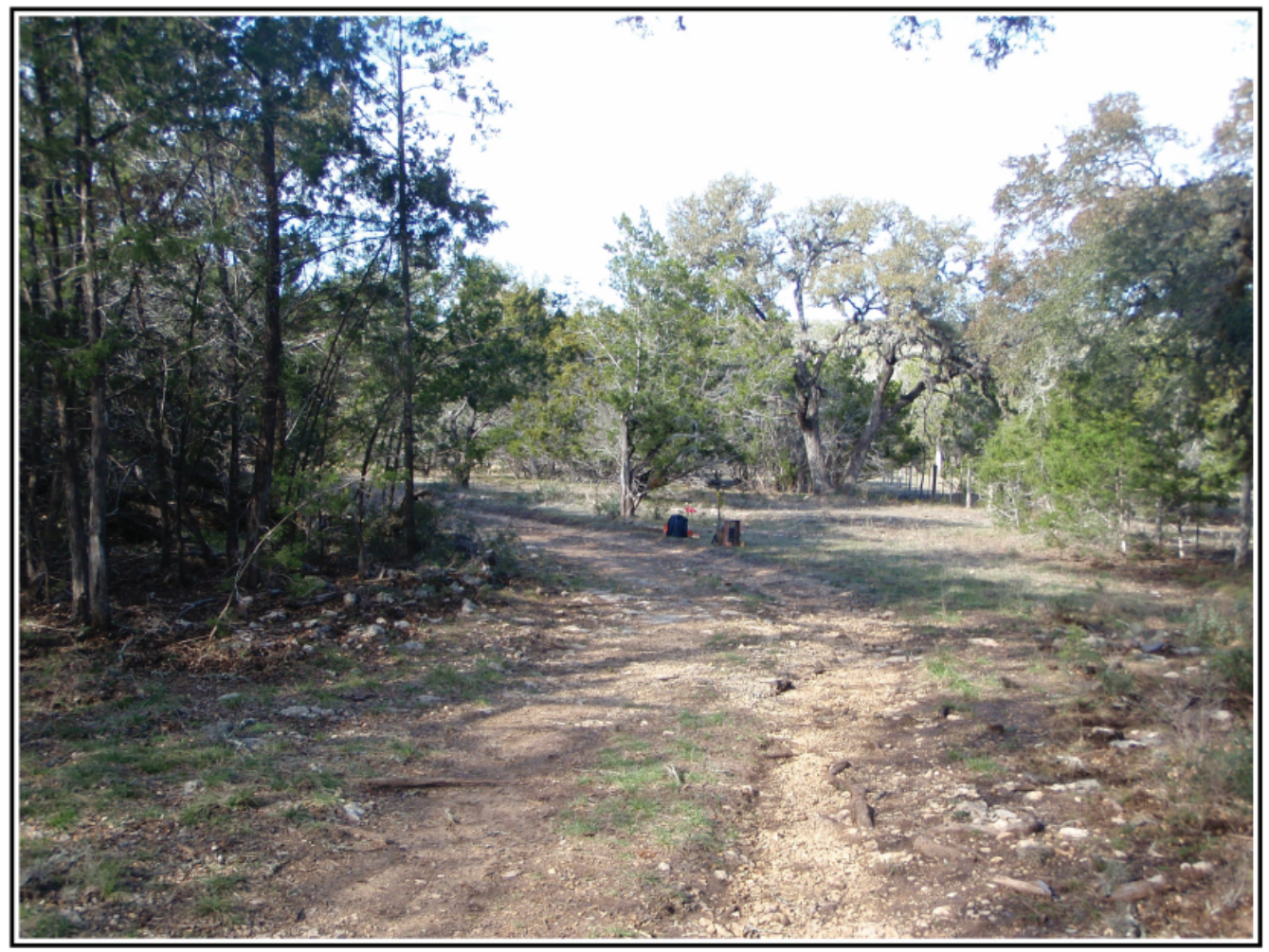

Figure 4-18. Overview of southern section of 41 KE214 (note park road and vegetation on sides of road). 


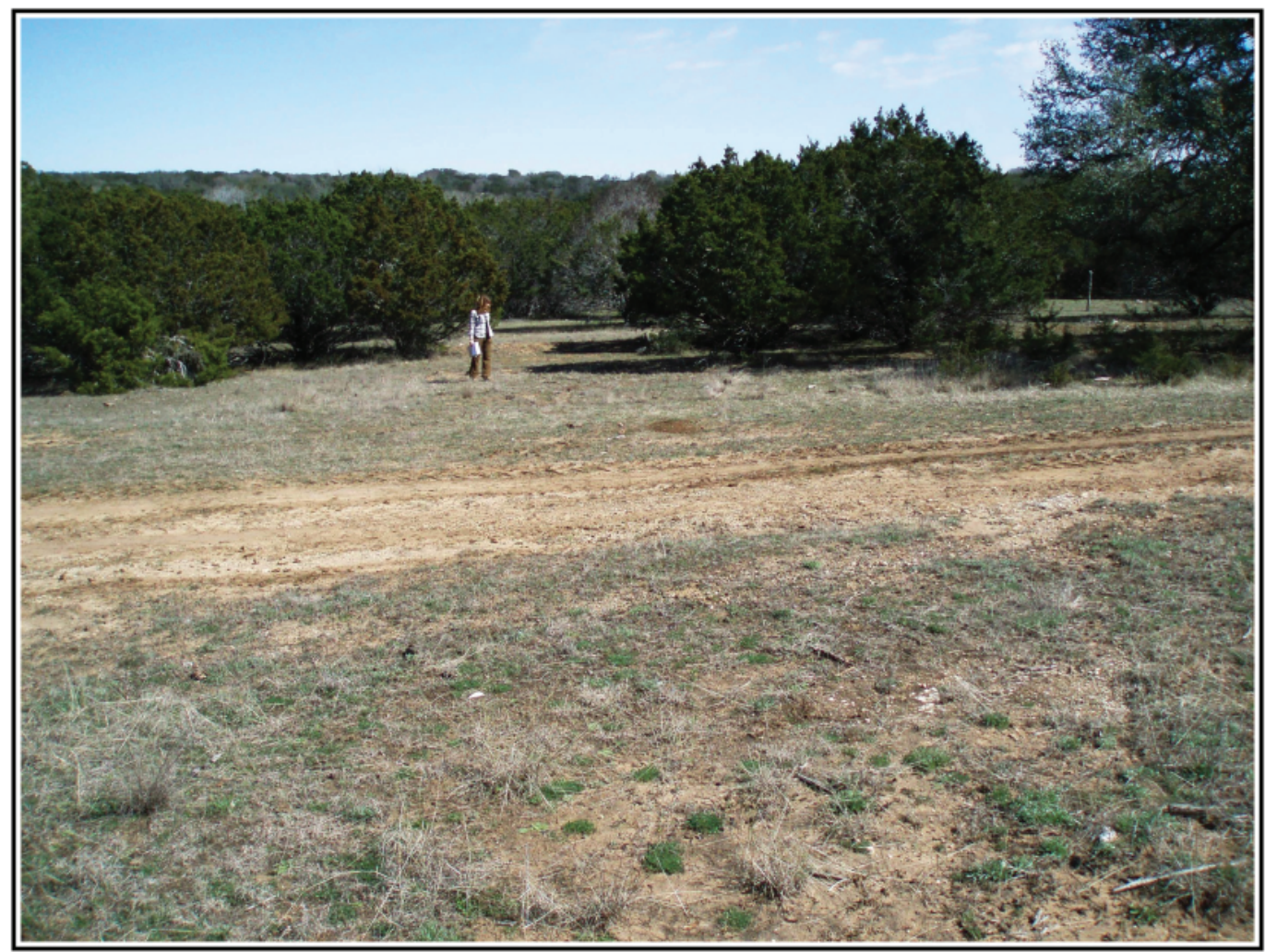

Figure 4-19. Overview of northern section of $41 \mathrm{KE} 214$ (note sides of park road are clear).

\section{Summary of the Archaeological Survey}

The survey of the Kendall County Park project used an intensive pedestrian survey accompanied by shovel testing and backhoe trenching to investigate proposed improvements of an existing park road and the 117 acre property. Sixty-four shovel tests were excavated resulting in the removal of approximately 1.5 cubic meters of sediment. No artifacts were recovered from shovel testing. Eighteen isolated surface finds, consisting of debitage, tools, burned rock, and a core, were recorded. One isolated boulder containing two mortar holes was documented. One new archaeological site, 41KE214, consisting of a surface scatter of lithic debitage, tools, and burned rock with no associated staining or charcoal was recorded. No features were noted on the site. The lack of material depth, features, and diagnostics, suggests that 41KE214 possesses low potential for future research value. Upon completion of the Center for Archaeological Research's shovel testing of site 41KE214, the Texas Historic Commission requested the excavation of additional shovel tests to confirm the extent of the site and the lack of deep deposits. A summary of the additional work is presented in an appendix to this report. Because the property contains a terrace adjacent to the Guadalupe River, two backhoe trenches were excavated to address the high potential for deeply buried intact paleosols and cultural material. Both trenches revealed $1.5 \mathrm{~m}$ of fairly homogenous sandy sediment, free of inclusions, grading from a grayish brown on the surface to a lighter brown at the base. No cultural material was noted in the trench walls or in the backfill dirt. A large existing cutbank near the river was profiled to document a larger extent of the terrace. The absence of mottling in the cutbank deposits indicates that the terrace may have formed in place. The terrace does not seem to be the result of high energy flooding. 



\section{Chapter 5: Summary and Recommendations}

\section{Summary}

The Center for Archaeological Research (CAR) of the University of Texas at San Antonio conducted an intensive pedestrian archaeological survey of the Kendall County Park project area located near Boerne, Texas for the Commissioner's Court of Kendall County. The 117-acre project area, located approximately 8.7 miles northeast of Boerne, Texas, is bounded by the Guadalupe River to the north and a surface street to the south. The east and west boundaries consist of fence lines delineating private rural properties. The park will consist of picnic areas, trails, a park road, and a two parking areas. No excavation is anticipated during construction. The principal goal of the pedestrian survey was to identify and document all prehistoric and/or historic archaeological sites that may be impacted by the proposed improvements within the park. This report discussed the survey of this property conducted in February 2010.

The archaeological survey consisted of a 100 percent pedestrian reconnaissance of the 117 acre property with shovel testing, accompanied by a linear survey with shovel testing of the approximately 0.76 mile park road including the proposed parking areas, and backhoe trenching along the terrace of the Guadalupe River. The survey included the hand excavation of 64 shovel tests resulting in the removal of approximately 1.5 cubic meters of sediment and the mechanical excavation of two backhoe trenches. No artifacts were recovered from the shovel tests. Eighteen isolated surface finds, including debitage, tools, one core, and burned rock, in addition to an isolated find consisting of two mortar holes in a large boulder were documented. No features were observed on the project area. Because the property contains a terrace adjacent to the Guadalupe River, two backhoe trenches were excavated to address the high potential for deeply buried intact paleosols and cultural material. Both trenches revealed $1.5-\mathrm{m}$ of fairly homogenous sandy deposits, free of inclusions, grading from a grayish brown on the surface to a lighter brown at the base. No cultural material was noted in the trench walls or in the backfill dirt. A large existing cutbank near the river was profiled to document a larger extent of the terrace. The absence of mottling in the cutbank soils indicates that the terrace probably is not the result of high energy flooding episodes, and most likely formed in place.

In the process of conducting the Kendall County Park survey one new site, 41KE214, was identified. The site, consisting of a surface scatter of lithic debitage, tools, and burned rock with no associated staining or charcoal, is located directly on the park road. Shovel tests excavated to delineate the site were all negative. No diagnostic artifacts were noted. Upon completion of the CAR's shovel testing of site 41KE214, the Texas Historic Commission requested the excavation of additional shovel tests to confirm the extent of the site and the lack of deep deposits (see Appendix A). The CAR excavated 22 additional shovel tests on and around 41KE214 to supplement the ones excavated previously resulting in 34 shovel tests associated with the site. Of the 34 shovel tests, 1 was positive. This test produced two pieces of debitage and a point base. The base places the site in the Transitional Archaic. After finishing the additional shovel testing, under the advisement of the THC, the CAR completed a one hundred percent surface collection of the artifacts on $41 \mathrm{KE} 214$ to mitigate any impacts of the proposed park road and parking area improvements and impacts from future artifact collection by park visitors. Lithic material recovered from the surface consisted of 204 specimens of debitage, 2 point fragments, 7 bifaces, 3 retouched flakes, and 2 cores.

Two sinkholes and one cave were documented during the pedestrian reconnaissance. The openings of all three were considerably large and the depth of each was substantial making them potential locations of prehistoric human interments.

\section{Recommendations}

The intensive pedestrian survey of the Kendall County Park project area was completed in accordance with State Historic Preservation laws and the mandates of the Antiquities Code of Texas. The work adhered to the requirements of Section 106 of the NHPA. One new site, 41KE214, was documented during the pedestrian survey. The lack of material depth, features, and diagnostic artifacts, suggests that $41 \mathrm{KE} 214$ possesses a low potential for future research value. Because of the lack of material depth and diagnostics, the CAR recommends that the site be considered ineligible for listing on the NRHP. The $\mathrm{CAR}$, under advisement from the THC, recommends that the improvements to the existing road and the construction of the parking areas proceed as proposed with the caveat that work conducted in the area of 41 KE214 be monitored by personnel from the CAR to document any cultural features that may be exposed. Additionally, the CAR recommends that the cave and sinkhole openings be protected to prevent exploration and looting of potential cultural material until these locations are assessed for significance. 



\section{References Cited}

Arbingast, S. A.

1976 Atlas of Texas. Bureau of Business Research, The University of Texas at Austin.

Barker, R. A., P. W. Bush and E. T. Baker, Jr. 1994 Geologic History and Hydrogeologic Setting of the Edwards-Trinity Aquifer System, West-Central Texas. Water Resources Investigations Report 94-4039. U.S. Geological Survey, Earth Science Center, Washington, D.C.

Barnes, V. E.

1983 Geological Atlas of Texas. San Antonio Sheet. Robert Hamilton Cuyler Memorial ed. Bureau of Economic Geology, The University of Texas at Austin.

Bement, L. C.

1991 The Thunder Valley Burial Cache: Group Investment in a Central Texas Sinkhole Cemetery. Plains Anthropologist 36(135):97-109.

1994 Hunter-Gatherer Mortuary Practices During the Central Texas Archaic. The University of Texas Press, Austin.

Black, S. L.

1986 The Clemente and Herminia Hinojosa Site, 41JW8: A Toyah Horizon Campsite in Southern Texas. Special Report No. 18. The Center for Archaeological Research, The University of Texas at San Antonio.

1989 Central Texas Plateau Prairie. In From the Gulf Coast to the Rio Grande: Human Adaptation in Central, South and Lower Pecos Texas, edited by T. R. Hester, S. L. Black, D. G. Steele, B. W. Olive, A. A. Fox, K. J. Reinhard and L. C. Bement, pp. 17-38. Research Series No. 33. Arkansas Archeological Survey, Fayetteville.

Black, S. L. and D. G. Creel

1997 The Central Texas Burned Rock Midden Reconsidered. In Hot Rock Cooking on the Greater Edwards Plateau: Four Burned Rock Midden Sites in West Central Texas, edited by S. L. Black, L. W. Ellis, D. G. Creel and G. T. Goode, pp. 446-515. Studies in Archeology 22. Texas Archeological Research Laboratory, The University of Texas at Austin.

Black, S. L. and A. J. McGraw

1985 The Panther Springs Creek Site: Cultural Change and Continuity in the Upper Salado Creek Drainage, SouthCentral Texas. Archaeological Survey Report, No 100. Center for Archaeological Research, The University of Texas at San Antonio.

Blair, W. F.

1950 The Biotic Provinces of Texas. The Texas Journal of Science 2(1):93-117.

Collins, M. B.

1995 Forty Years of Archeology in Central Texas. Bulletin of the Texas Archeological Society 66:361-400.

1998 Wilson-Leonard: An 11,000 Year Archeological Record of Hunter-Gatherers in Central Texas. Studies in Archeology 31. Texas Archeological Research Laboratory. The University of Texas at Austin. 
Davis, W. B. and D. J. Schmidly

1994 The Mammals of Texas. Texas Parks and Wildlife, Austin.

Dittemore, W. H., Jr. and J. L. Hensell

1981 Soil Survey of Kendall County, Texas. United States Department of Agriculture, Soil Conservation Service.

Foster, W. C.

1998 The La Salle Expedition to Texas: The Journal of Henri Joutel 1664-1687. Texas State Historical Association, Austin.

Givins, R. D.

1968 A Preliminary Report on Excavations at Hitzfelder Cave. Bulletin of the Texas Archeological Society 38:47-50.

Handbook of Texas Online

2010 Kendall County. Electronic Document. http://www.tshaonline.org/handbook/online $/ \operatorname{articles} / \mathrm{KK} / \mathrm{hck} 3 . \mathrm{html}$, accessed March 2010.

Hester, T. R.

1995 The Prehistory of South Texas. Bulletin of the Texas Archeological Society 66:427-459.

Hester, T. R., A. Sullivan, L. Froelich and R. S. Crawford Jr.

1998 Notes on South Texas Archaeology 1998-2002: Artifacts and Burials from a Vertical Shaft Cave, Site 41UV356, Uvalde County, Texas. La Tierra 25(2):1-5.

Houk, B. A., K. A. Miller and E. R. Oksanen 2008 The Gatlin Site (41KR621): Investigating Archaic Lifeways on the Southern Edwards Plateau of Central Texas. SWCA Cultural Resources Report No. 2008-149. SWCA Environmental Consultants, Austin.

Johnson, L. and G. Goode

1994 A New Try at Dating and Characterizing Holocene Climates, as well as Archaeological Periods, on the Eastern Edwards Plateau. Bulletin of the Texas Archeological Society 65:1-15.

Kutac, E. A.

1994 Birds. In Birds \& Other Wildlife of South Central Texas, edited by E. A. Kutac and S. C. Caran, pp. 47-102. University of Texas Press, Austin.

Mauldin, R. P., D. L. Nickels and C. J. Broehm

2003 Archaeological Testing to Determine the National Register Eligibility Status of 18 Prehistoric Sites on Camp Bowie, Brown County Texas. Archaeological Survey Report, No. 334. Center for Archaeological Research, The University of Texas at San Antonio.

Nickels, D. L.

2000 The Beisenbach Site (41WN88): A Case Study in Diet Breadth. Unpublished Master's Thesis, The University of Texas at San Antonio.

Perttula, T. K.

2001 Hunter-Gatherer Mortuary Practices in the Rio Grande Plains and Central Coastal Plains Archeological Regions of Texas. La Tierra 28(3\&4):2-83. 
Potter, D. R., R. B. Pickering and C. E. Mear 2005 Salvage Excavation at the Coleman Cemetery Site, 41BX568. La Tierra 32(1).

Prewitt, E. R. 1981 Culture Chronology in Central Texas. Bulletin of the Texas Archeological Society 52:65-89.

Riemenschneider, L. and S. A. Turpin 1998 Boat-Shaped Mortars in Crockett County, Texas. La Tierra 25(1):36-41.

Scruggs, L., J. Gunn and N. Hitzfelder 1978 The Hitzfelder Bone Collection. La Tierra 5(2):20-30.

Soil Survey Staff 2010 Web Soil Survey. Natural Resources Conservation Service, United States Department of Agriculture. http:// websoilsurvey.nrcs.usda.gov/ accessed March 2010.

Spearing, D.

1991 Roadside Geology of Texas. Roadside Geology Series. Mountain Press Publishing Company, Missoula.

Tankersley, K. B. and B. L. Isaac

1990 Early Paleoindian Economies of North America. JAI Press, Greenwich, Connecticut.

Taylor, R.

1996 The New Handbook of Texas in Six Volumes. The Texas State Historical Association, Austin.

Texas Historical Commission 2010 Texas Archeological Site Atlas. http://nueces.thc.state.tx.us/, accessed March 2010.

TPWD

2010 GIS Vegetation Types of Texas. http://www.tpwd.state.tx.us/publications/pwdpubs /pwd_bn_w7000_0120/ woods/, accessed March 2010.

Turpin, S. A.

1988 Seminole Sink: Excavation of a Vertical Shaft Tomb, Val Verde County, Texas. Memoir 22. Plains Anthropologist 33(122, Part 2).

Turpin, S. A. and L. C. Bement 1988 Seminole Sink: Excavation of a Vertical Shaft Tomb, Val Verde County, Texas. The Site and its Setting, compiled by S. A. Turpin. Memoir 2. Plains Anthropologist 33(122, part 2):1-18. 

Appendix A:

Additional Shovel Testing and Surface Collection at 41KE214 

Upon completion of the Center for Archaeological Research's shovel testing of site 41KE214, the Texas Historic Commission requested the excavation of additional shovel tests to confirm the extent of the site and the lack of deep deposits. The CAR excavated 22 additional shovel tests on and around 41KE214 to supplement the ones excavated previously, resulting in 34 shovel tests associated with the site. Ten of these were within the site and 24 were in the immediate area (Figure A-1).

The shovel tests on the northern portion of the site hit bedrock within approximately three levels $(30 \mathrm{cmbs})$, whereas the tests on the southern portion were shallow, often terminating on bedrock before the completion of Level 1 (10 cmbs; Table A-1). Of the 34 shovel tests, 1 (ST RM9) located near the center of the site immediately west of the existing road was positive. This test, which terminated upon the exposure of bedrock at $4 \mathrm{cmbs}$, produced two pieces of debitage and a point base. The base, a possible Fairland, Edgewood, or Ensor, places the site in the Transitional Archaic, approximately 200B.C.-A.D. 600 (Turner and Hester 1999).

After finishing the additional shovel testing, and in consultation with the THC, the CAR completed a surface collection of all artifacts on $41 \mathrm{KE} 214$. This was designed to mitigate any impacts of the proposed park road and parking

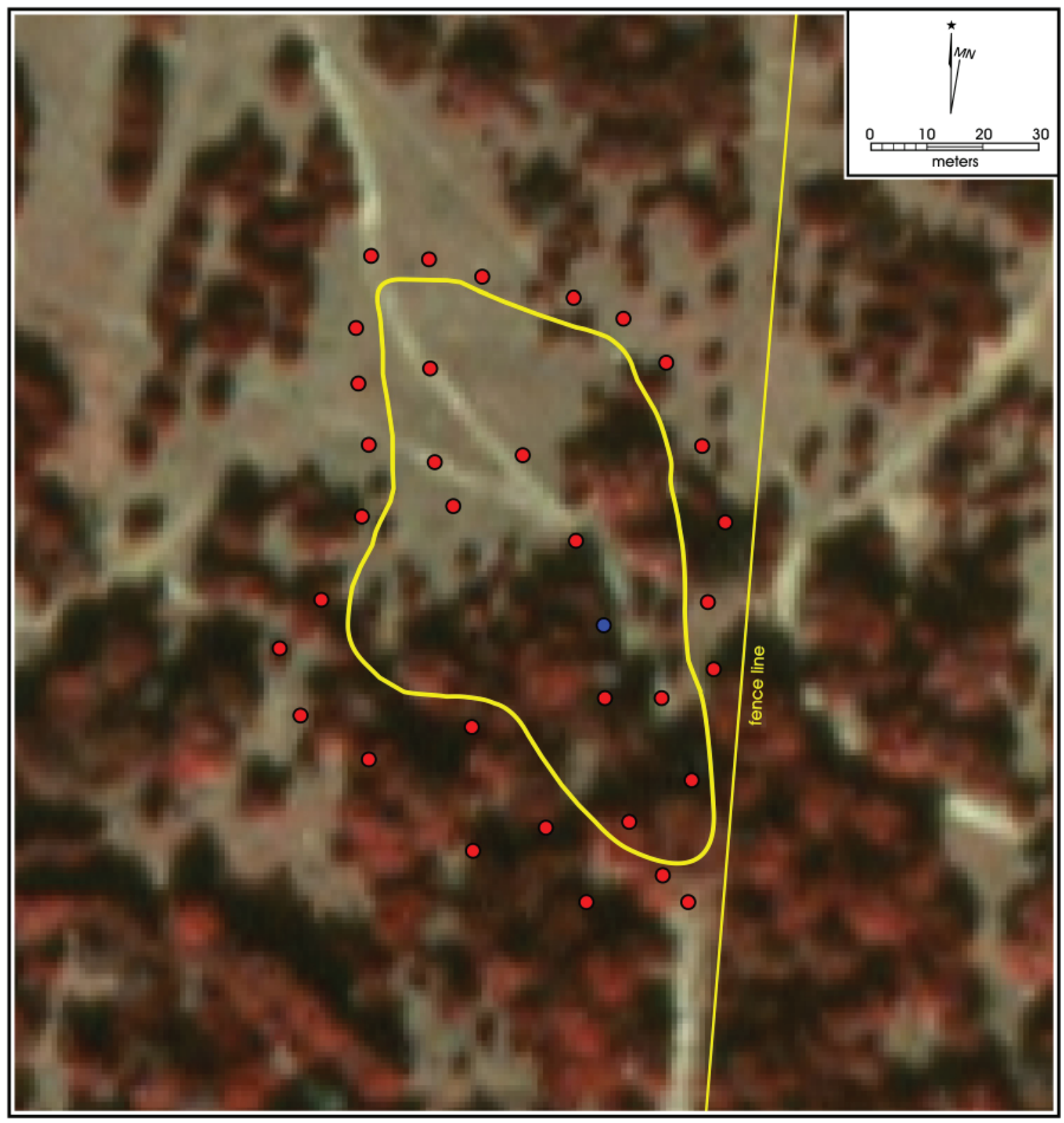

Figure A-1. Aerial view of $41 \mathrm{KE} 214$ showing location of positive (blue) and negative shovel tests (red). 
Table A-1. Termination Depths of Additional Shovel Tests on $41 \mathrm{KE} 214$

\begin{tabular}{|c|c|c|c|c|c|}
\hline $\begin{array}{c}\text { Shovel } \\
\text { Test }\end{array}$ & $\begin{array}{c}\text { Termination } \\
\text { Level }\end{array}$ & $\begin{array}{c}\text { Depth } \\
\text { (cmbs) }\end{array}$ & $\begin{array}{c}\text { Shovel } \\
\text { Test }\end{array}$ & $\begin{array}{c}\text { Termination } \\
\text { Level }\end{array}$ & $\begin{array}{c}\text { Depth } \\
\text { (cmbs) }\end{array}$ \\
\hline CM1 & 3 & 26 & LM7 & 3 & 28 \\
\hline CM2 & 2 & 14 & LM8 & 2 & 13 \\
\hline CM3 & 1 & 9 & RM1 & 3 & 22 \\
\hline CM4 & 1 & 8 & RM2 & 3 & 24 \\
\hline CM5 & 2 & 19 & RM3 & 2 & 12 \\
\hline LM1 & 2 & 15 & RM4 & 3 & 21 \\
\hline LM2 & 3 & 29 & RM5 & 3 & 24 \\
\hline LM3 & 2 & 16 & RM6 & 1 & 4 \\
\hline LM4 & 2 & 11 & RM7 & 3 & 24 \\
\hline LM5 & 2 & 12 & RM8 & 1 & 5 \\
\hline LM6 & 1 & 5 & RM9 & 1 & 4 \\
\hline
\end{tabular}

area improvements, and any impacts from future artifact collections. All the material was point provenienced using a Sokkia Set 6E total station in conjunction with a Carlson Explorer SurvCE data collector. Lithic material recovered from the surface consisted of 204 specimens of debitage, 2 point fragments, 7 bifaces, 3 retouched flakes, and 2 cores (Figure A-2). The point fragments, a base and an ear, are both probable Castroville dating to the Late Archaic (800-400 B.C.; Turner and Hester 1999).

A basic analysis was conducted of the lithic debitage to attempt to isolate any artifact patterns on 41KE214. Each specimen of debitage was weighed and examined for evidence of patination and cortex presence or absence. Of the 204 specimens $21.6 \%(n=44)$ contain cortex and $19.1 \%(n=39)$ are patinated. Of the patinated specimens

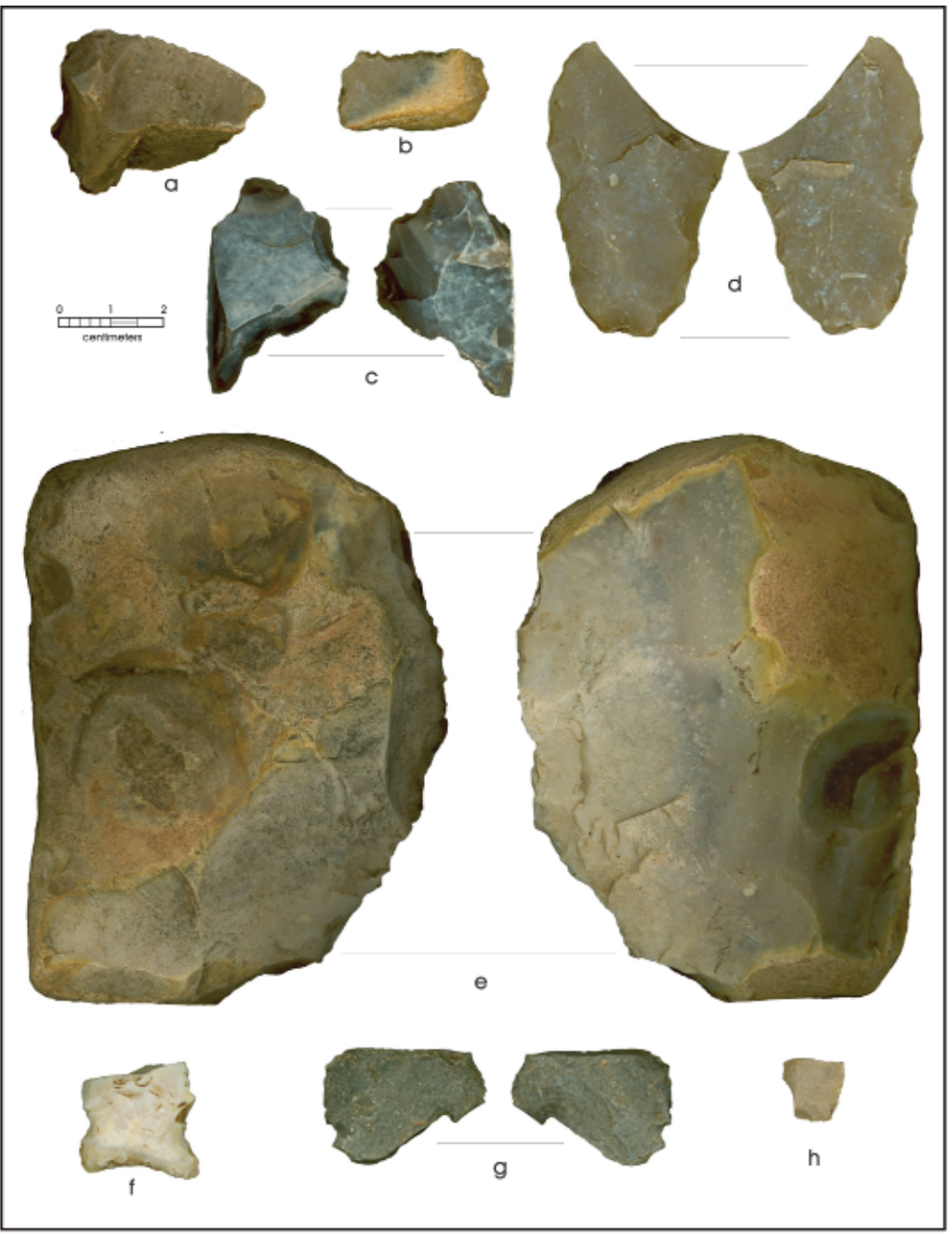

Figure A-2. Artifacts from 41KE214: $a$-b) retouched flakes; $c$-e) bifaces; $f$ - $h$ ) projectile point fragments. 
$89.7 \%$ lack cortex, opposed to $78.8 \%$ of the nonpatinated pieces.

Figure A-3 shows all the surface collected debitage by their north and east coordinates. Clearly, exposure conditioned much of the distribution. The majority of debitage, identified in blue in Figure A-3, falls within a portion of the extant road bed, which is about 5 to $10 \mathrm{~cm}$ below the surrounding ground surface. This area also contained all three projectile points, including the one recovered from the shovel test, and most of the other tools. Several other clusters are also present, which are color coded as Groups 1, 2, and 3 in the figure. Finally, a small amount of debitage, identified in red, are outside of any defined cluster. The three smaller clusters, identified by yellow, orange, and green in Figure A-3, are not associated

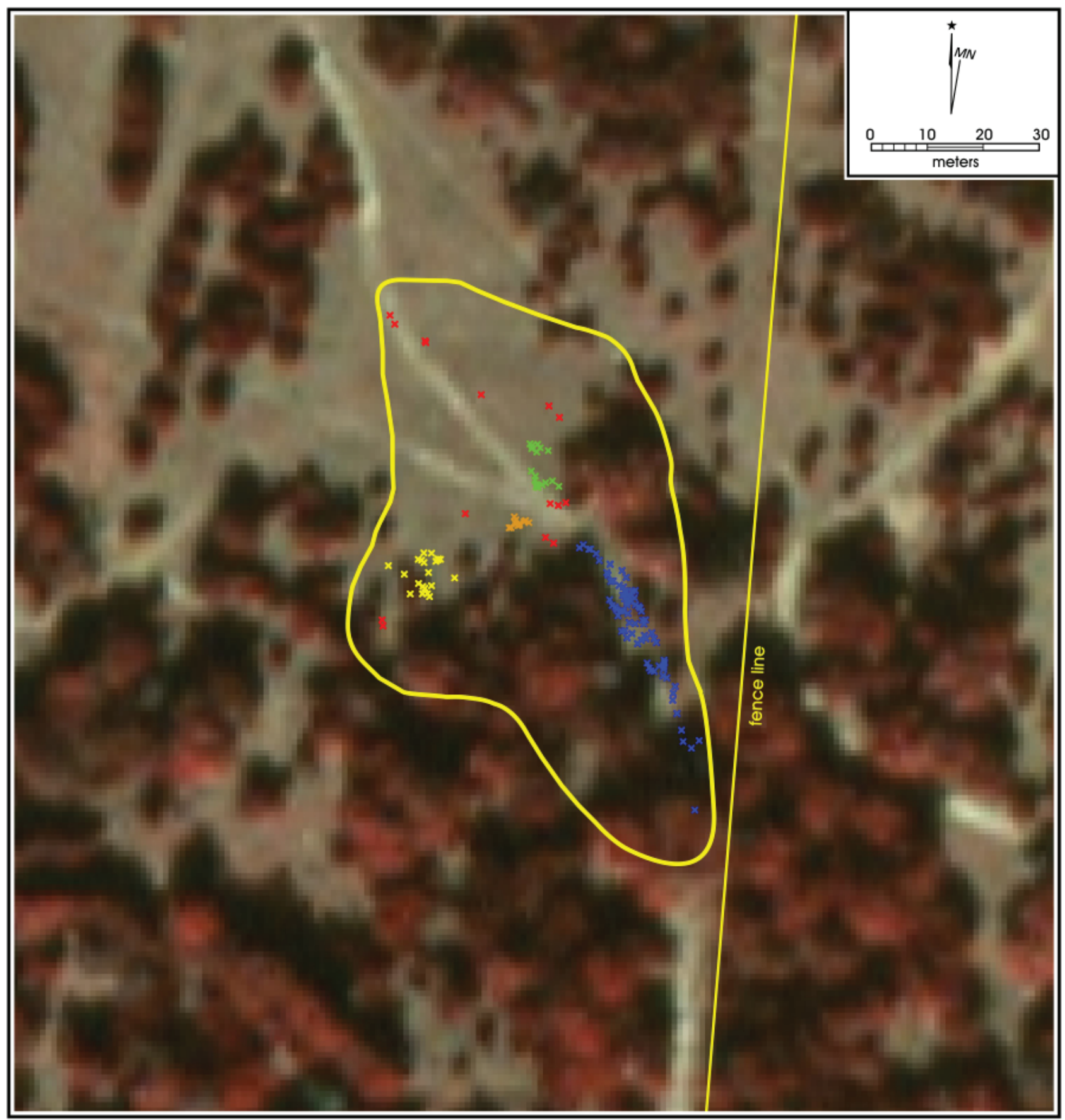

Figure A-3. Distribution of debitage on 41 KE214 showing distinct clusters of materials ( $1=y e l l o w ; 2=$ orange; $3=$ green; $4=$ blue, $5=$ red). 
directly with the road exposure. Group 1 is at a slightly higher elevation, sitting on an area with shallow limestone. Groups 2 and 3 are on either side of the road, and form relatively small concentrations of material.

Table A-2. Debitage Clusters at 41KE214

\begin{tabular}{|c|c|c|c|}
\hline Group & \% Patinated & \% Noncortical & $\begin{array}{c}\text { Mean weight } \\
\text { (gm) }\end{array}$ \\
\hline 1 & 27.3 & 90.9 & 1.4 \\
\hline 2 & 31.3 & 75.0 & 2.1 \\
\hline 3 & 30.0 & 90.0 & 2.2 \\
\hline $4+5$ & 14.1 & 74.1 & 3.5 \\
\hline
\end{tabular}

Comparison of the three smaller clusters (Groups 1, 2, and 3) to the debitage in the road and outside of the clusters (Groups 4 and 5) indicates that the clusters contain higher percentages of patinated debitage suggesting older material (Table A-2). Archaeologists working with lithic materials have repeatedly concluded that chert patination is related to material age. Patination appears to be progressive (Frederick et al. 1994).
Two of the groups (1 and 3) have higher percentages of noncortical material. Primary flakes have the dorsal face completely covered by cortex, secondary flakes have some cortex on their dorsal side, and tertiary flakes have no cortex. High frequencies of primary flakes are assumed to be indicative of early reduction, and high frequencies of tertiary flakes are assumed to reflect late reduction. The amount of cortex should be less on late reduction specimens and greater on early reduction pieces (Andrefsky 1998).

The size of lithic debitage is another attribute commonly used to determine reduction patterns. The mean weight was determined for each artifact cluster (see Table A-2). Mean debitage weight was plotted at a $95 \%$ confidence interval by surface cluster location (Figure A-4). This figure suggests a significant size reduction in Group 1 debitage when compared to the weights of debitage from the road (Group 4) and materials outside of the clusters (Group 5). Debitage size, as reflected by weight, in Groups 2 and 3 is also reduced when compared to Groups 4 and 5. Based on the assumption that late stage reduction results in small noncortical flakes,

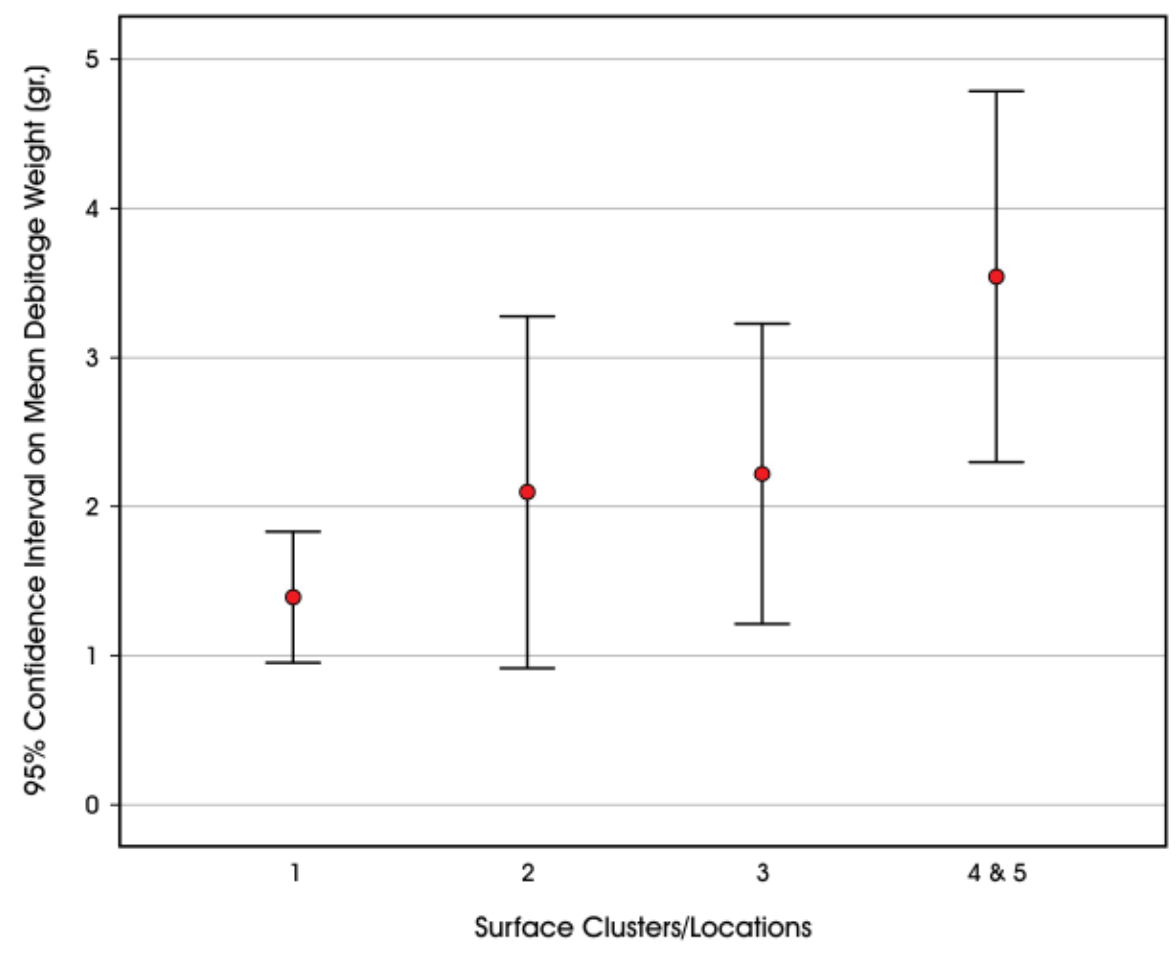

Figure A-4. Plot comparing debitage weighed by location on 41KE214. 
the debitage assemblage located in Group 1 appears to be the result of late stage reduction. The material in Groups 2 and 3, also smaller than the nonclustered artifacts, may also represent late stage reduction, although Group 2 contains a higher percentage of corticate material.

The distribution and description of the surface material from $41 \mathrm{KE} 214$ suggests, then, that at least two, and possibly three or more periods of occupation are present. The temporal diagnostic artifacts reflect both Transitional Archaic and Late Archaic occupations were present in this area. While it is impossible to separate these two distributions spatially, the cortex patterns and size of debitage, as well as the tools recovered, suggest a generalized reduction strategy focused on bifacial tools. The higher degrees of patination in the Group 1,2, and 3 debitage suggests that this material may be earlier than the Late Archaic material in the road, though how much earlier remains unclear. The Groups 1 and 3 debitage reflect later reduction, with a low frequency of cortical flakes and smaller overall size when compared to the Group 4 and 5 materials. The Group 2 cluster has a similar percentage of patinated material when compared with Groups 1 and 3, but the higher frequency of cortical flakes in the Group 2 material suggests a different pattern of reduction. It remains unclear if the Group 2 cluster also reflects a distinct temporal occupation at $41 \mathrm{KE} 214$.

\section{References Cited}

Andrefsky, W., Jr. 1998 Lithics: Macroscopic Approaches to Analysis. University Press, Cambridge.

Frederick, C. D., M. D. Glascock, H. Neff and C. M. Stevenson 1994 Evaluation of Chert Patination as a Dating Technique: A Case Study from Fort Hood, Texas. Research Report No. 32. Archaeological Resource Management Series, United States Army, Fort Hood. Mariah Associates, Austin.

Turner, S. E. and T. R. Hester 1999 A Field Guide to Stone Artifacts of Texas Indians. Third ed. Gulf Publishing, Houston. 